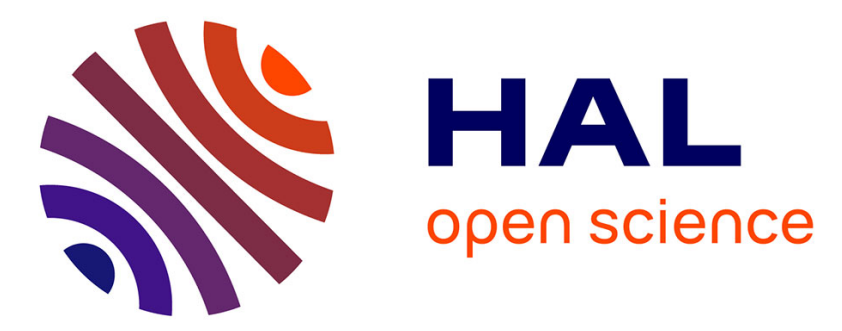

\title{
Evaluation of aerosol indirect radiative forcing in MIRAGE
}

\author{
Steven Ghan, Richard Easter, James Hudson, Francois-Marie Breon
}

\section{To cite this version:}

Steven Ghan, Richard Easter, James Hudson, Francois-Marie Breon. Evaluation of aerosol indirect radiative forcing in MIRAGE. Journal of Geophysical Research: Atmospheres, 2001, 106 (D6), pp.5317-5334. 10.1029/2000JD900501 . hal-03120979

\section{HAL Id: hal-03120979 \\ https://hal.science/hal-03120979}

Submitted on 19 Mar 2021

HAL is a multi-disciplinary open access archive for the deposit and dissemination of scientific research documents, whether they are published or not. The documents may come from teaching and research institutions in France or abroad, or from public or private research centers.
L'archive ouverte pluridisciplinaire HAL, est destinée au dépôt et à la diffusion de documents scientifiques de niveau recherche, publiés ou non, émanant des établissements d'enseignement et de recherche français ou étrangers, des laboratoires publics ou privés. 


\title{
Evaluation of aerosol indirect radiative forcing in MIRAGE
}

\author{
Steven Ghan and Richard Easter \\ Pacific Northwest National Laboratory, Richland, Washington
}

James Hudson

Desert Research Institute, Reno, Nevada

Francois-Marie Bréon

CEA Laboratoire des Sciences du Climat et de l'Environnement, Gif-sur-Yvette, France

\begin{abstract}
We evaluate aerosol indirect radiative forcing simulated by the Model for Integrated Research on Atmospheric Global Exchange (MIRAGE). Although explicit measurements of aerosol indirect radiative forcing do not exist, measurements of many of the links between aerosols and indirect radiative forcing are available and can be used for evaluation. These links include the cloud condensation nuclei concentration, the ratio of droplet number to aerosol number, the droplet number concentration, the column droplet number, the column cloud water, the droplet effective radius, the cloud optical depth, the correlation between cloud albedo and droplet effective radius, and the cloud radiative forcing. The $\mathrm{CCN}$ concentration simulated by MIRAGE agrees with measurements for supersaturations larger than $0.1 \%$ but not for smaller supersaturations. Simulated droplet number concentrations are too low in most but not all locations with available measurements, even when normalized by aerosol number. MIRAGE correctly simulates the higher droplet numbers and smaller droplet sizes over continents and in the Northern Hemisphere. Biases in column cloud water, cloud optical depth, and shortwave cloud radiative forcing are evident in the Intertropical Convergence Zone and in the subtropical oceans. MIRAGE correctly simulates a negative correlation between cloud albedo and droplet size over remote oceans for cloud optical depths greater than 15 and a positive correlation for cloud optical depths less than 15 but fails to simulate a negative correlation over land.
\end{abstract}

\section{Introduction}

One of the greatest sources of uncertainty in estimates of anthropogenic climate change is in the estimate of the indirect radiative forcing, in which aerosol particles are activated to form cloud droplets, thereby influencing cloud reflectivity by changing the droplet effective radius [Twomey, 1977; Charlson et al., 1992] and the cloud liquid water content [Fouquart and Isaka, 1992; Hudson, 1993; Rotstayn, 1999]. The uncertainty in estimates of the global mean indirect radiative forcing by anthropogenic aerosol is roughly $1.5 \mathrm{~W} \mathrm{~m}^{-2}$, which is more than half the present global mean radiative forcing due to anthropogenic increases in greenhouse gas concentrations, and comparable to the global mean of the sum of the forcing by increasing greenhouse gases and the direct forcing by anthropogenic aerosols [Intergovernmental Panel on Climate Change (IPCC), 1995]. The total present-day anthropogenic forcing can therefore range from less than $1 \mathrm{~W} \mathrm{~m}^{-2}$ to more than $4 \mathrm{~W} \mathrm{~m}^{-2}$. The uncertainty in the indirect component of the anthropogenic aerosol forcing must be substantially reduced if the anthropogenic signal of climate change is to be detected in the observed climate record and if

Copyright 2001 by the American Geophysical Union.

Paper number 2000JD900501.

0148-0227/01/2000JD900501\$09.00 predictions of future climate change are to be useful for assessing climate impacts and developing a policy for mitigating climate change.

How can the uncertainty be reduced? Penner et al. [1994] and the National Research Council (NRC) [1996] Panel on Aerosol Radiative Forcing and Climate Change describe a strategy involving a combination of in situ measurements, satellite measurements, and modeling studies designed to evaluate and improve understanding of the key processes involving direct as well as indirect radiative forcing. This strategy has led to increasing sophistication in global model estimates of indirect forcing. Several global modeling groups have applied empirical relationships between pollutant concentrations and cloud droplet number to estimate the indirect forcing [Jones et al., 1994; Boucher and Lohmann, 1995; Jones and Slingo, 1996; Lohmann and Feichter, 1997; Rotstayn, 1999]. More recently, Ghan et al. [1997b] introduced a physically based relationship between aerosol concentration and cloud droplet number, which Chuang et al. [1997] and Lohman et al. [1999] applied to global coupled chemistry-aerosol circulation models. These physically based models are necessary to separate the natural and anthropogenic components of the forcing and to consider future scenarios of emissions of aerosols and their precursor gases.

The Pacific Northwest National Laboratory (PNNL) Model for Integrated Research on Atmospheric Global Exchange (MIRAGE) was developed for such a purpose. It consists of a 
detailed global tropospheric chemistry and aerosol model that predicts concentrations of oxidants as well as aerosols and aerosol precursors, coupled to a general circulation model that predicts cloud water and cloud ice mass and cloud droplet and ice crystal number concentrations [Ghan et al., 1997a,b]. Both number and mass of several externally mixed lognormal aerosol size modes are predicted, with internal mixing assumed for the different aerosol components within each mode. Predicted aerosol species include sulfate, organic and black carbon, nitrate, soil dust, and sea salt. The climate model uses physically based treatments of aerosol radiative properties (including dependence on relative humidity) and aerosol activation as cloud condensation nuclei. More detailed descriptions of the chemistry and aerosol treatment in MIRAGE are presented by R. C. Easter et al. (manuscript in preparation, 2000) (hereinafter referred to as E2000). Ghan et al. [this issue (a)] describe the treatment of water uptake and aerosol radiative properties. The treatments of cloudaerosol interactions and cloud radiative properties in MIRAGE are described in section 3 of this paper.

Before models can be used to estimate the anthropogenic aerosol radiative forcing, they must be thoroughly evaluated. E2000 evaluate the simulation of the concentrations of the aerosols and their precursor gases by MIRAGE. Ghan et al. [this issue (a)] evaluate the simulation of the aerosol direct forcing. In this paper we evaluate the simulation of the aerosol indirect forcing by MIRAGE. Ghan et al. [this issue (b)] apply MIRAGE to estimate the direct and indirect forcing by anthropogenic sulfate particles.

\section{Evaluation Strategy}

Evaluation of the simulated aerosol indirect forcing requires measurements of a variety of fields related to aerosol indirect forcing. Our evaluation strategy is to employ a suite of complementary and redundant measurements to evaluate the aerosol indirect forcing simulated by MIRAGE. E2000 evaluate the aerosol concentration simulated by MIRAGE. We therefore begin our evaluation by examining the cloud condensation nuclei (CCN) concentrations simulated by MIRAGE. We then proceed on to the relationship between droplet and aerosol number concentrations, the droplet number concentration, the cloud liquid water path, the cloud droplet effective radius, the cloud optical depth, and finally the cloud radiative forcing. It should be noted that although none of the fields is a measure of the aerosol indirect forcing, successful simulation of all of the fields would greatly increase confidence in estimates of aerosol indirect forcing by the same model.

The evaluation focuses on the 12-month period June 1994 to May 1995 simulated by MIRAGE. Nudging toward European Center for Medium-Range Weather Forecasting (ECMWF) analyzed winds, temperature, and sea surface temperature is applied to reduce the influence of natural variability on the interpretation of the results [Feichter and Lohmann, 1999]. The simulation was performed at a horizontal resolution of T42 (about $2.8^{\circ}$ latitude and longitude) with 24 levels, about half in the boundary layer. Measurements for the same time period are used in the evaluations whenever possible, but measurements from other years had to be used in some cases. Nudging reduces the need for multiyear simulations because the simulated circulation systems are constrained to follow those observed.

\section{Evaluation}

\subsection{Cloud Condensation Nuclei Concentration}

The first step in the connection between aerosols and indirect forcing is the Cloud Condensation Nuclei (CCN) concentration. If a model fails to simulate a realistic distribution of $\mathrm{CCN}$ as a function of supersaturation, then one cannot expect it to correctly simulate the cloud droplet number concentration. To evaluate the simulated CCN spectra, we have compiled a climatology of CCN spectra measured by the Desert Research Institute CCN spectrometer [Hudson, 1989] at various field experiments. Table 1 lists the approximate latitude, longitude, and dates of each of the field experiments. Additional information about the $\mathrm{CCN}$ measurements is described by Hudson and Li [1995], Hudson et al. [1999], Hudson and Xie [1999], Hudson and Yum [1999], and Yum and Hudson [2000]. The measurements have been averaged over all samples within each $100 \mathrm{hPa}$ layer that measurements were available. To compare with the measurements, we have selected the MIRAGE grid cell and simulated month closest

Table 1. Field Experiments Whose CCN Measurements Were Used for Model Evaluation

\begin{tabular}{lccll}
\hline \multicolumn{1}{c}{ Experiment } & Latitude & Longitude & \multicolumn{1}{c}{ Region } & \multicolumn{1}{c}{ Period } \\
\hline FIRE $^{\mathrm{a}} 1$ & 33 & 238 & California coast & June-July 1987 \\
ASTEX $^{\mathrm{b}}$ & 38 & 332 & Azores & June 1992 \\
SOCEX $^{\mathrm{c}} 1$ & -42 & 142 & Tasmania & July 1993 \\
SOCEX 2 $^{\text {d }}$ & -42 & 142 & Tasmania & Jan.-Feb. 1995 \\
SCMS $^{\mathrm{d}}$ & 30 & 280 & Florida & July-Aug. 1995 \\
ACE $^{\mathrm{e}}$ 1 & -45 & 145 & Tasmania & Nov.-Dec. 1995 \\
ARM $^{\mathfrak{l}}$ IOP & 38 & 262 & Oklahoma & Sept.-Oct. 1997 \\
FIRE 3 & 72 & 210 & Arctic Ocean & May 1998 \\
\hline
\end{tabular}

${ }^{\mathrm{a}}$ FIRE, First International Satellite Cloud Climatology Project Regional Experiment.

${ }^{b}$ ASTEX, Atlantic Stratocumulus Transition Experiment.

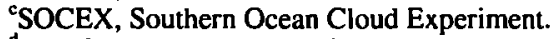

${ }^{d}$ SCMS, Small Cumulus Microphysics Study.

AACE, Aerosol Characterization Experiment.

${ }^{f}$ ARM, Atmospheric Radiation Measurement program. 

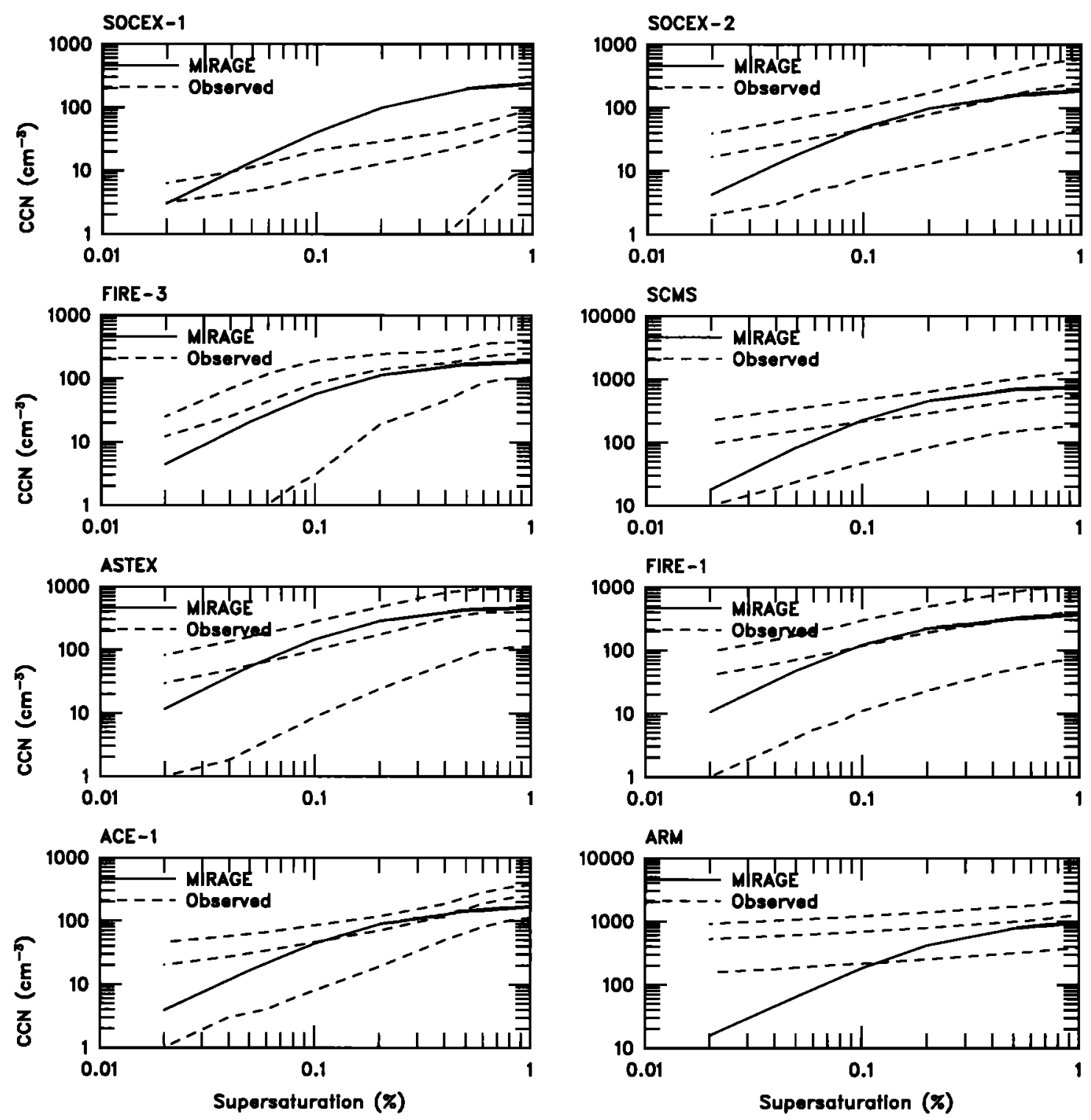

Figure 1. Cloud Condensation Nuclei (CCN) concentration as a function of supersaturation, averaged over all measurements at pressures between 800 and $900 \mathrm{hPa}$ during each of eight field experiments (dashed line) and averaged over the closest month and grid cell for the same pressure interval in the Model for Integrated Research on Atmospheric Global Exchange (MIRAGE) simulation (solid line). The additional dashed lines indicate the 10 th and 90 th percentiles of the measurements.

to that of each field experiment. The simulated CCN concentration at supersaturations of $0.02,0.05,0.1,0.2,0.5$, and $1 \%$ is calculated each time step using the Köhler equilibrium theory applied to the aerosol size distribution and composition simulated by MIRAGE for each of the four lognormal aerosol modes treated in MIRAGE. Note that $\mathrm{CCN}$ with $S=0.02$, $0.05,0.1,0.2$, and $0.5 \%$ correspond to sea-salt particles with chy diameters of $0.33,0.18,0.11,0.072$, and $0.039 \mu \mathrm{m}$, or ammonium sulfate particles with dry diameters of $0.39,0.21$, $0.13,0.084$, and $0.046 \mu \mathrm{m}$.

Figure 1 compares simulated and observed CCN spectra averaged over pressures between 800 and $900 \mathrm{hPa}$ for all measurements at each experiment location. Although the simulated CCN concentrations at supersaturations $S$ of $0.1-1 \%$ are quite close to those observed for all but one experiment (Southern Ocean Cloud Experiment (SOCEX) 1, in which
MIRAGE overestimates the $\mathrm{CCN}$ concentration by a factor of 5-10), MIRAGE consistently simulates significantly fewer $\mathrm{CCN}$ at $S=0.02 \%$. This suggests that either MIRAGE simulates too few coarse particles or the $\mathrm{CCN}$ spectrometer overestimates the CCN concentration for $S=0.02 \%$. MIRAGE neglects many potential sources of coarse mode particles, such as bacteria [Matthias-Maser and Jaenicke, 1994; Lighthart and Shaffer, 1994], pollen, fungal spores, viruses, and algae. However, the number concentrations for such coarse mode particles are generally much lower than the measured $\mathrm{CCN}$ concentrations at $S=0.02 \%$, so it is unlikely that these missing sources can account for the discrepancy. Alternatively, the simulated $\mathrm{CCN}$ concentration at $S=0.02 \%$ could also be increased by prescribing broader aerosol size distributions for the accumulation mode in MIRAGE, which would also reduce the simulated $\mathrm{CCN}$ concentration at higher 

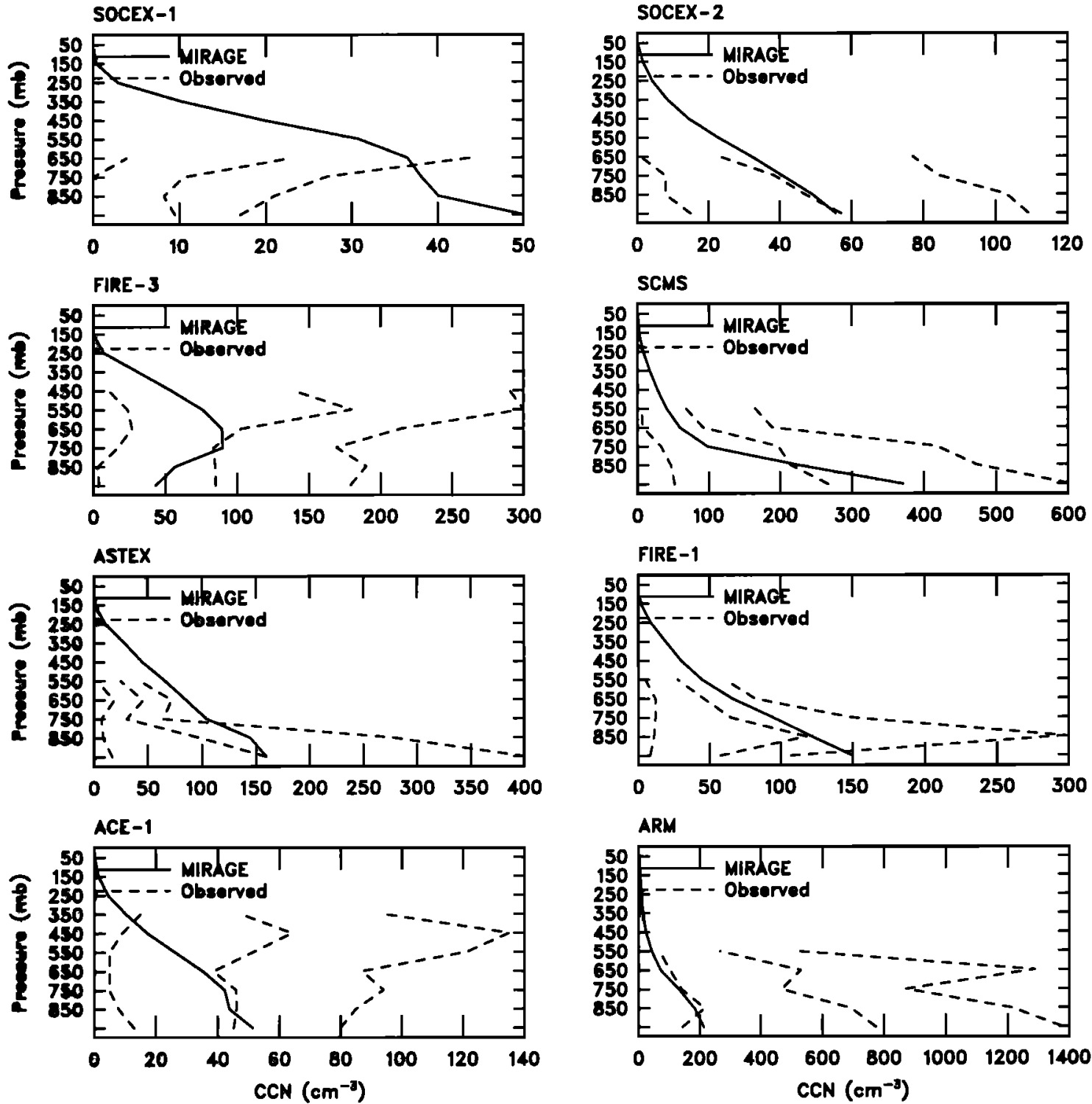

Figure 2. Time mean vertical profiles of the CCN concentration at a supersaturation of $0.1 \%$, as measured during each field experiment (dashed line) and as simulated by MIRAGE during the same time of year and at the closest grid cell. The additional dashed lines indicate the 10th and 90th percentiles of the measurements.

supersaturations. However, the width of the aerosol size distribution required for consistency with the CCN spectra is incomsistent with measured aerosol size distributions.

On the other hand, Wood et al. [2000] have found a similar difference in the slopes of the CCN spectra as measured during the second Aerosol Characterization Experiment and as estimated from Köhler theory using the measured aerosol size distribution. This suggests that the difference between the MIRAGE simulation and the measurements at $S=0.02 \%$ may not be due to missing $0.4 \mu \mathrm{m}$ diameter particles in MIRAGE. Recent comparisons between $\mathrm{CCN}$ spectrometer measurements have indicated that the $\mathrm{CCN}$ measurements at low concentrations (such as at a supersaturation of $0.02 \%$ ) can overestimate the CCN concentration by perhaps a factor of 2 . After the CCN data (shown in Figure 1) were analyzed, it came to our attention, mainly from analysis of comparisons with other CCN counters at a workshop in 1997 [J. Snider et al., manuscript in preparation, 2000], that the Desert Research Institute (DRI) CCN spectrometer data needs to be corrected. This correction is needed because of the inherent spreading of signals within the instrument, which causes channels (corresponding to derived critical supersaturations) that should have high counts to be underestimated and channels that should have low counts to be overestimated. This does not alter the total concentrations of $\mathrm{CCN}$ but usually causes an overestimate of concentrations at low $S$. This can be corrected by "inverting" the data according to the method used by Wendisch et al. [1996] using the iterative solution of Twomey [1975] as modified by Markowski [1987]. So far, these corrections indicate only small changes for $S>$ $0.1 \%$ and 10 to $100 \%$ overestimates at lower $S$. This accounts for at least some of the disagreement between simulations and observations at low $S$. The problem is especially acute for the ARM data since this is the only set of data acquired with the 
newer DRI CCN spectrometer, which has less resolution than the older one and will require more severe inversion corrections. This is probably why there are greater differences between simulations and observations at low $S$ for ARM.

Figure 2 compares vertical profiles of simulated and observed CCN concentration at $S=0.1 \%$ for each experiment. The measurements show a variety of vertical profiles: decreasing with height (ARM, ASTEX, SCMS, SOCEX 2), decreasing with height but depleted in the boundary layer (FIRE 1), nearly constant with height (ACE 1), and increasing with height (FIRE 3 and SOCEX 2). The simulated profiles tend to decrease with height, except for the FIRE-3 case (Arctic Ocean) where the simulated profile increases with height between 950 and $750 \mathrm{hPa}$, in agreement with the observations. The agreement between simulated and observed profiles is within the range of variability in the observations for all locations except the ARM IOP site, where MIRAGE underestimates the CCN concentration by a factor of 3-4, and SOCEX 1, where MIRAGE overestimates the CCN concentration in the planetary boundary layer by a factor of 3-4. The ARM site is located in a concentration gradient region in the central United States (lower concentrations to the west, higher concentrations to the east), and concentrations during a specific observational period would be expected to be sensitive to actual airflow patterns. The overprediction at SOCEX 1 is consistent with the excessive Methane Sulfonic Acid (MSA) and sulfate simulated at Cape Grim, Tasmania [E2000]. The excessive MSA may be due to excessive Dimethyl Sulfide (DMS) emissions in the Southern Ocean. However, E2000 conclude that the widespread excessive sulfate simulated by MIRAGE is due to inefficient wet removal that happens in winter with such clean air and abundant drizzle [e.g., Boers et al., 1996, 1998].

\subsection{Cloud Droplet Number Concentration}

The prediction of droplet number is perhaps the most important link in estimates of indirect radiative forcing. Given the CCN spectrum and the spectrum of updraft velocities, MIRAGE calculates the droplet nucleation rate and applies it to the droplet balance equation to predict the droplet number concentration [Ghan et al., 1997b]. Aerosol activation/droplet nucleation is parameterized using the multimode version [Abdul-Razzak and Ghan, 2000] of the single-mode parameterization developed by Abdul-Razzak et al. [1998]. The activation parameterization determines the mass and number fraction activated for each mode, which is then used to determine the droplet nucleation rate for the CCM and the aerosol mass and number nucleation rate for treating nucleation scavenging of the aerosol. The activation rate for a new cloud is given by the number activated in each new cloudy layer, divided by the time step. Activation for an old cloud is assumed to occur only at cloud base, where it is expressed in terms of a flux of nucleated droplets into the lowest layer of the cloud; the activation rate is then given by the flux convergence in the lowest layer in a manner consistent with the treatment of turbulent transport of droplets [Ghan et al., 1997b]. In contrast to other mechanistic treatments of droplet number [Chuang et al., 1997; Lohmann et al., 1999], no lower bound is placed on the simulated droplet number or aerosol number. However, a lower bound $\left(0.04 \mathrm{~m}^{2} \mathrm{~s}^{-2}\right)$ on the subgrid variance of vertical velocity is applied because the vertical
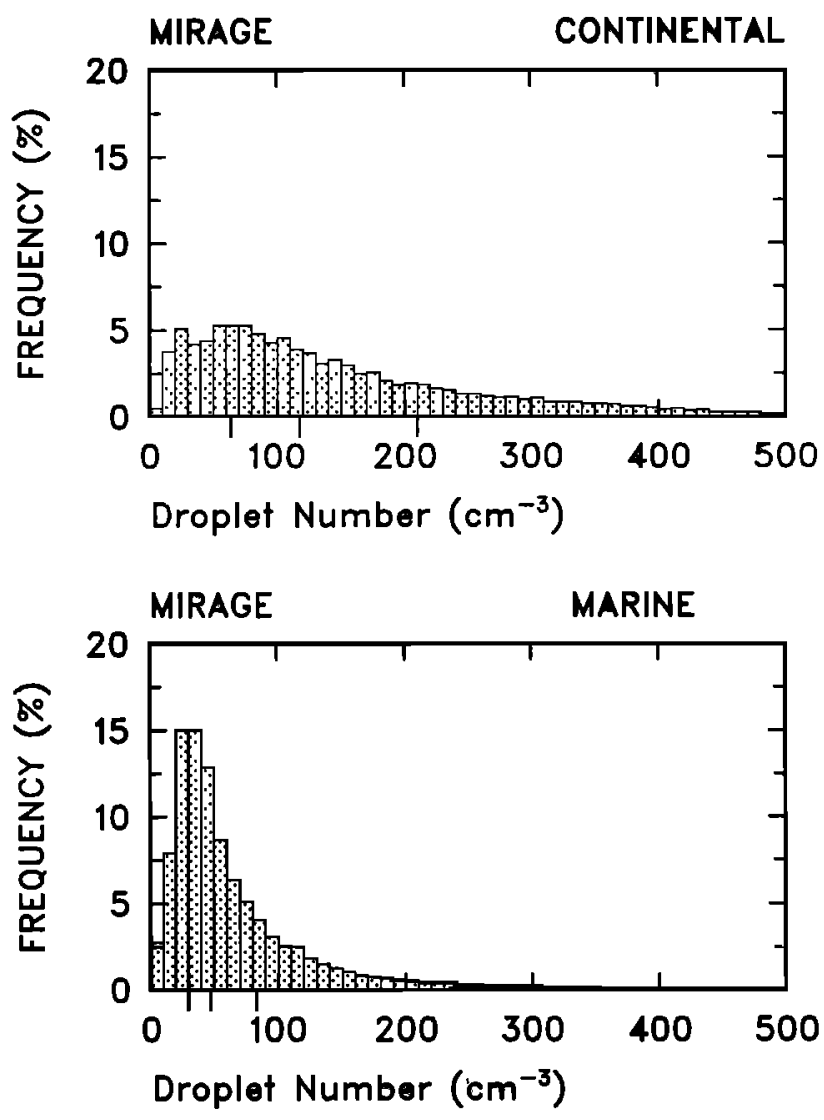

Figure 3. Spatial frequency distribution of the cloud waterweighted annual mean in-cloud droplet number concentration simulated by MIRAGE for continental (top) and marine (bottom) grid points. The three marks along each horizontal axis show the 25 th, $50 \mathrm{th}$, and 75 th percentiles.

resolution of MIRAGE is insufficient to resolve the cloud-top radiative cooling that drives turbulence in boundary layer clouds. The subgrid variance of vertical velocity is otherwise determined from the Yamada and Mellor [1979] second-order turbulence closure (level 2.5) model.

Droplet loss by collision/coalescence is expressed in terms of droplet number and cloud water using the Ziegler [1985] parameterization. Droplet loss by collection is treated by assuming collection of cloud water by rain, snow, and ice reduce droplet number and cloud water but not the average size of the cloud droplets. The treatment of droplet loss by mixing/evaporation is described by Ghan et al. [1997b].

Figure 3 shows the spatial frequency distribution of the annual mean in-cloud droplet number concentration simulated for continental and marine grid points. Consistent with in situ measurements [Squires, 1958; King et al., 1995], droplet number concentrations are typically higher in continental air than in marine air. The modian simulated droplet number concentration for marine and continental air is 47 and $117 \mathrm{~cm}^{-3}$, respectively. These concentrations are lower then most in situ measurements. For example, the median droplet number concentration for clean marine and continental air during the Atlantic Stratocumulus Transition Experiment (ASTEX) was estimated by King et al. [1995] to be 148 and $393 \mathrm{~cm}^{-3}$, respectively.

Most estimates of indirect forcing by global models [Jomes 


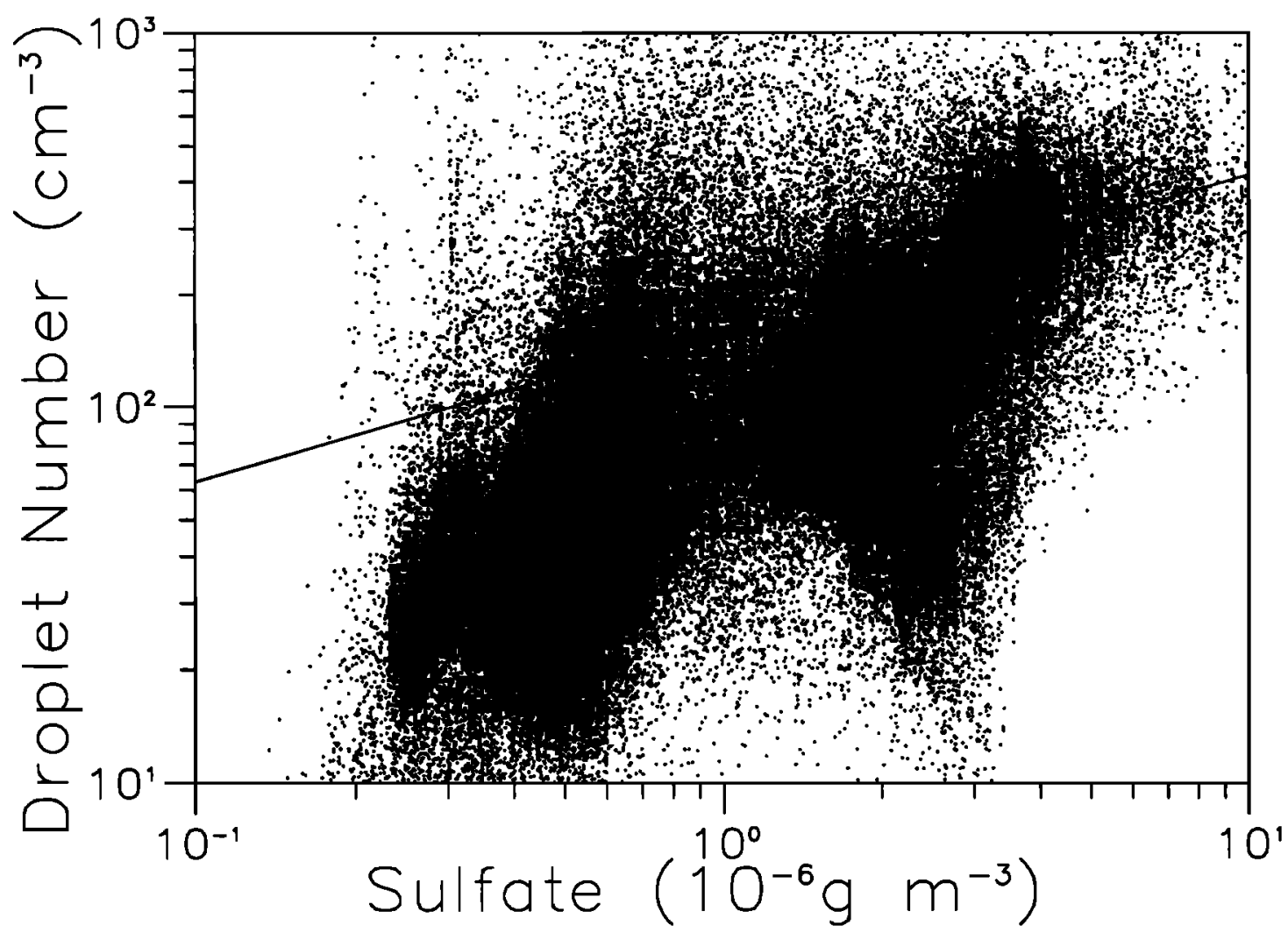

Figure 4. Simulated annual mean in-cloud droplet number concentration for all grid points plotted against the simulated annual mean sulfate mass concentration. The solid line shows empirical relationship $D$ of Boucher and Lohmann [1995].

et al., 1994; Boucher and Lohmann, 1995; Jones and Slingo, 1996; Feichter et al., 1997; Lohmann and Feichter, 1997; Rotstayn, 1999; Kiehl et al., 2000] have used empirical relationships between droplet number and either sulfate mass or aerosol number (determined from sulfate mass by assuming a prescribed aerosol size distribution). Figure 4 shows the relationship between droplet number concentration and sulfate mass concentration simulated by MIRAGE. The relationship is in excellent agreement with the empirical relationship $D$ of Boucher and Lohmann [1995], with droplet number concentrations increasing from 10 to $30 \mathrm{~cm}^{-3}$ for sulfate mass concentrations of $0.3 \mu \mathrm{g} \mathrm{m}^{-3}$ to $200-500 \mathrm{~cm}^{-3}$ for sulfate mass concentrations of $10 \mu \mathrm{g} \mathrm{m}^{-3}$. As in the measurements, sulfate mass concentration only explains a fraction of the variability in droplet number, which depends also on the aerosol size distribution, the turbulence kinetic energy both at cloud base and at cloud top, and the mass concentrations of other components of the CCN. Interestingly, the droplet number and sulfate mass concentrations cluster around two modes (20-50 droplets $\mathrm{cm}^{-3}, 0.4-0.6 \mu \mathrm{g} \mathrm{m}^{-3}$ sulfate, and 60-150 droplets $\mathrm{cm}^{-3}, 1.5-3 \mu \mathrm{g} \mathrm{m}^{-3}$ sulfate). This bimodality is suggestive of Baker and Charlson's [1990] multiple equilibrium hypothesis (clean-precipitating cloud and dirty-nonprecipitating cloud). A more likely explanation is the very different sulfur emissions in industrial and remote regions.

Another test of the prediction of droplet number in MIRAGE is to compare the ratio of droplet number to aerosol number (interstitial plus activated) with in situ measurements. This provides a test of the treatment of cloud-aerosol interactions, which is less sensitive to the aerosol simulation than the droplet number concentration itself. Figure 5 plots the ratio versus the aerosol number to show how the ratio depends on the aerosol number. Comparable measurements are available in the work of Gillani et al. [1995]. Both the measurements and the simulation indicate that the ratio decreases with increasing aerosol number, reflecting the increasing competition for water (and hence lower maximum supersaturations) at higher aerosol concentrations. However,

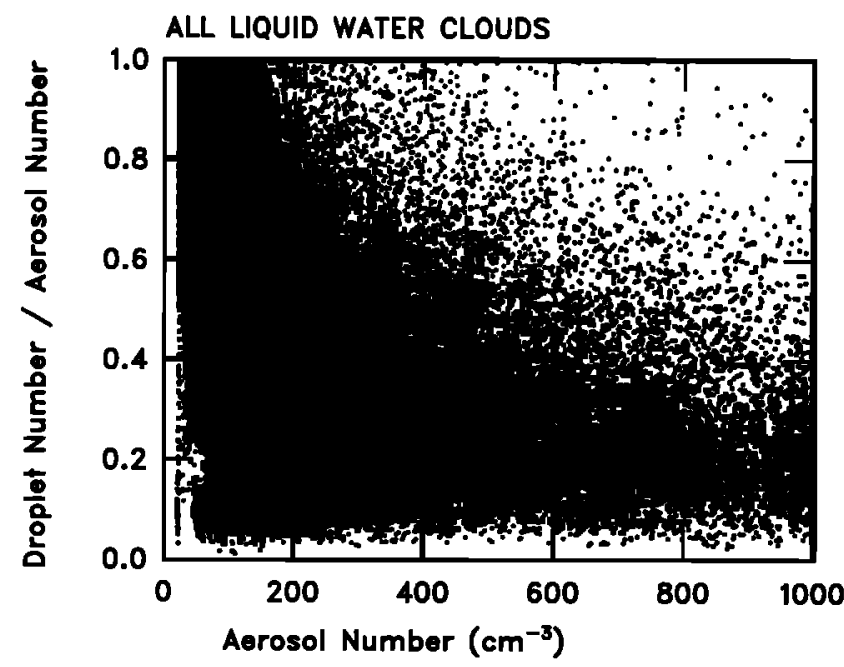

Figure 5. MIRAGE simulation of the ratio of droplet number to aerosol number (interstitial plus activated) plotted versus aerosol number for all grid cells. 


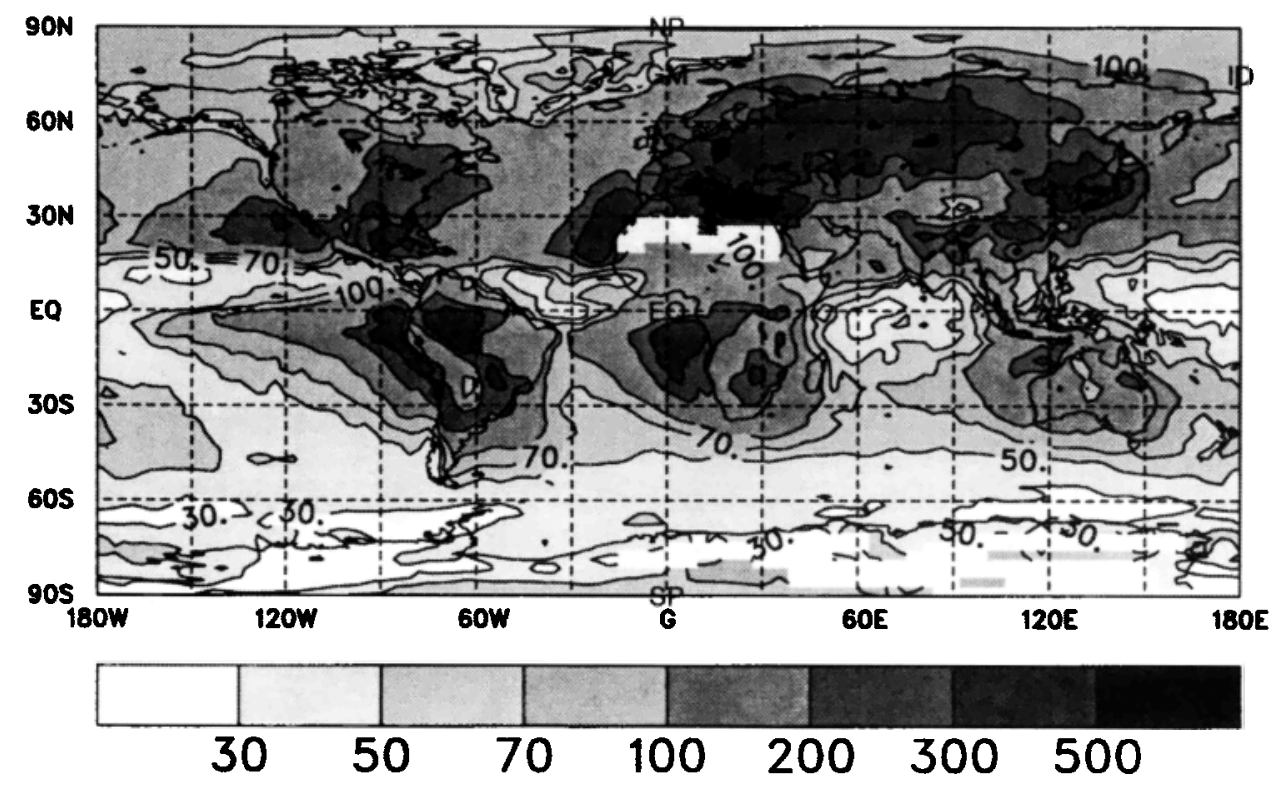

Figure 6. Cloud-water-weighted vertical and annual mean in-cloud droplet number concentration $\left(\mathrm{cm}^{-3}\right)$ simulated by MIRAGE.

the ratio simulated by MIRAGE is significantly smaller than the measured ratio (the fact that the measurements do not sample particles smaller than radius $0.085 \mu \mathrm{m}$ has been accounted for by subtracting the number smaller than the cutoff size from the simulated aerosol number). This bias suggests that either activation is underestimated in MIRAGE or the droplet sinks due to mixing/evaporation, collision/coalescence of droplets, and collection by precipitating hydrometeors are overestimated.

The treatment of activation has been evaluated by Gultepe et al. [1996] and Lin and Leaitch [1997]. Although Gultepe et al. found good agreement between the parameterized number activated and the observed droplet number if the measured standard deviation of vertical velocity is used in the activation parameterization, $\mathrm{Lin}$ and Leaitch found that the parameterized activation underestimates the droplet number if the parameterization is applied in the same way as in MIRAGE, i.e., by integrating over the subgrid frequency distribution of vertical velocity. The bias is larger than the difference between the parameterized activation and that calculated by a detailed model [Abdul-Razzak and Ghan, 2000], suggesting that the problem is not with the parameterization itself but with the treatment of subgrid variability.

The horizontal distribution of the cloud water-weighted vertical and annual mean in-cloud droplet number is illustrated in Figure 6. Simulated droplet number concentrations are greatest near the regions with the largest emissions of primary particles and aerosol precursor gases and least in regions far from the largest emissions and where aerosol removal by precipitation is most frequent. Mean droplet concentrations are $30-60 \mathrm{~cm}^{-3}$ in the Aerosol Characterization Experiment (ACE 1) region south of Tasmania, smaller than the measured values of $30-120 \mathrm{~cm}^{-3}$ [Yum et al., 1998; Boers and Krummel, 1998]. The simulated droplet concentrations over the northeast United States and southeast Canada (200$300 \mathrm{~cm}^{-3}$ ) are consistent with measurements there [Leaitch et al., 1992]. The simulated droplet concentrations in the northwest Atlantic Ocean $\left(150-200 \mathrm{~cm}^{-3}\right)$ are somewhat lower than in situ measurements during the North Atlantic Regional Experiment [Leaitch et al., 1996]. The droplet number simulated near the Azores $\left(200-400 \mathrm{~cm}^{-3}\right)$ is actually somewhat higher than values of $50-300 \mathrm{~cm}^{-3}$ measured during ASTEX [King et al., 1995; Hudson and Li, 1995; Hudson and Yum, 1997].

Global information about droplet number concentration is available from the Han et al. [1998b] analysis of Advanced Very High Resolution Radiometer (AVHRR) measurements and International Satellite Cloud Climatology Project (ISCCP) for the year 1987. Figure 7 compares the annual means of the simulated and observed column droplet number concentrations. Although interpretation of the column droplet number in terms of droplet number concentration is complicated by variations in cloud depth, several conclusions can be drawn from Figure 7. First, MIRAGE correctly simulates higher column droplet number concentrations in the industrial regions of the United States, Europe, and East Asia compared to over the oceans. Second, over the major deserts (Sahara, Gobi, and Australia) the column droplet number simulated by MIRAGE is an order of magnitude less than that estimated from satellite measurements, but as noted by the Han et al. [1998b] satellite anaiysis over the deserts is probably detecting dust rather than cloud droplets. These conclusions are further supported by an examination of the zonal mean column droplet number (Figure 8 ), which indicates good agreement between the MIRAGE simulation and the observations except at the latitudes of the deserts, where the observed column droplet number is larger.

\subsection{Cloud Liquid Water Path}

One of the key fields that determine the cloud albedo and the planetary radiation balance is the cloud liquid water path, also known as column cloud water. MIRAGE predicts stratiform cloud liquid water content using Ghan and Easter's [1992] simplification of the Colorado State University Regional Atmospheric Modeling System parameterization of 

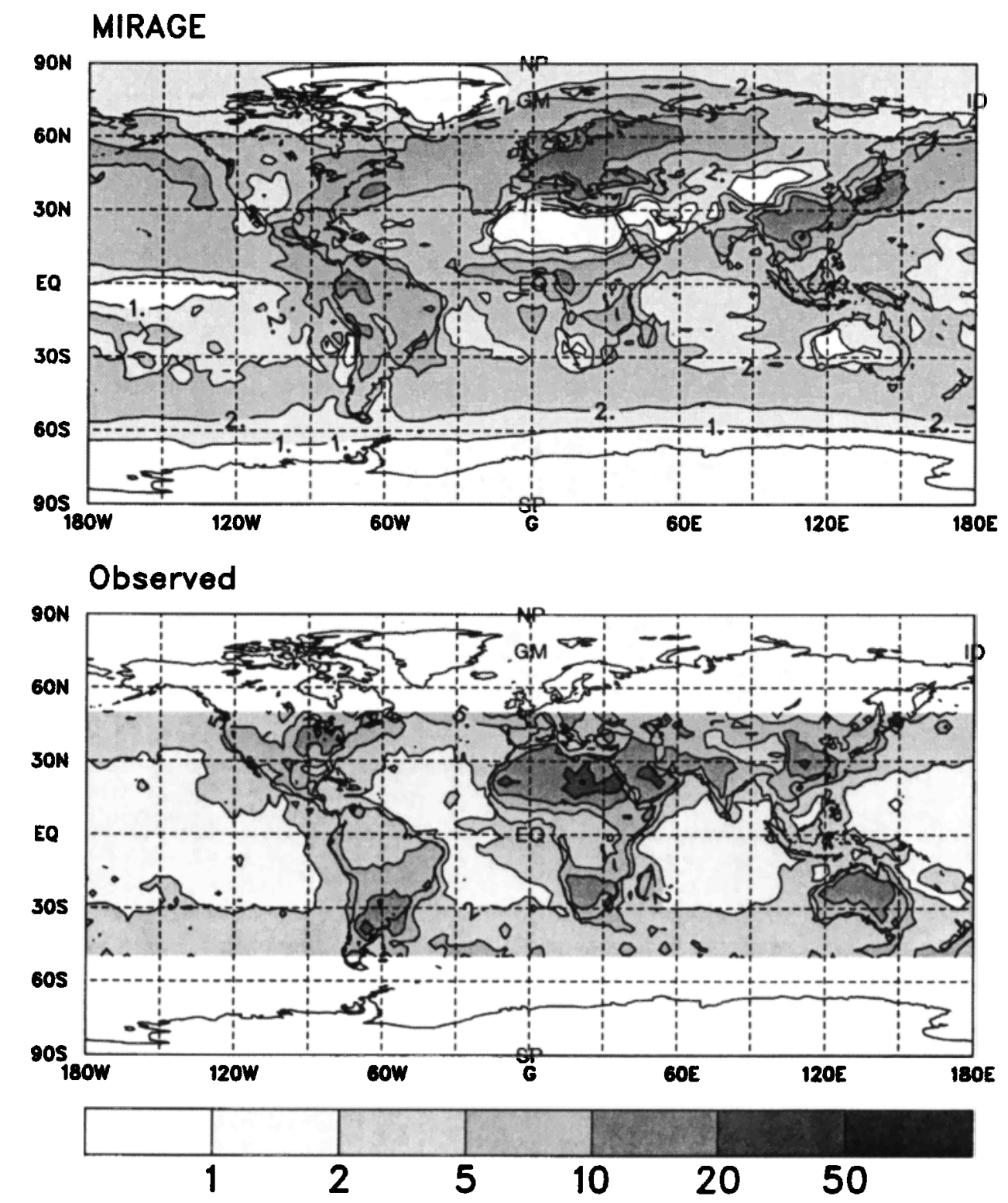

Figure 7. Annual mean column droplet number concentration $\left(10^{6} \mathrm{~cm}^{-2}\right)$ simulated by MIRAGE and estimated from satellite measurements by the Han et al. [1998b].

bulk cloud microphysics [Tripoli and Cotton, 1980; Cotton et al., 1986]. Subgrid variability in cloud liquid water is presently neglected. Convective cloud liquid water is also neglected. Figure 9 compares the monthly and ocean mean column cloud water simulated by MIRAGE with an estimate from multiyear Special Sensor Microwave/Imager measurements [Greenwald et al., 1995] for January and July. SSM/I measurements of column cloud water are not possible over land. Although the simulated column cloud water agrees with the measurements to within $30 \%$ in the midlatitude storm tracks, MIRAGE overestimates the column cloud water by a factor of 2 in most of the Intertropical Convergence Zone (ITCZ) and underestimates it by a factor of 2-3 in most of the subtropics. The positive bias in the ITCZ may be due to the limitations of the SSM/I analysis in precipitating clouds, but it should be noted that the simulated ITCZ is much weaker without nudging toward analyzed winds. The negative bias in the subtropics is probably due to deficiencies in the shallowconvection parameterization in MIRAGE.

\subsection{Cloud Droplet Efrective Radius}

Another key field that determines cloud albedo is the cloud droplet effective radius, which in MIRAGE is expressed in terms of droplet number and liquid water content [Ghan et al., 1997a]. Two different estimates are available from measurements. Figure 10 compares the zonal land and ocean mean effective radius simulated by MIRAGE for January 1995 and July 1994 with that estimated from International Satellite Cloud Climatology Project (ISCCP) data by Han et al. [1994] for January and July 1987 . The simulated values represent cloud-water-weighted means over the depth of the ,cloud, which according to in situ measurements [Nichols, 1984] might be systematically smaller than the value near cloud top, which is estimated from the satellite retrieval algorithm 


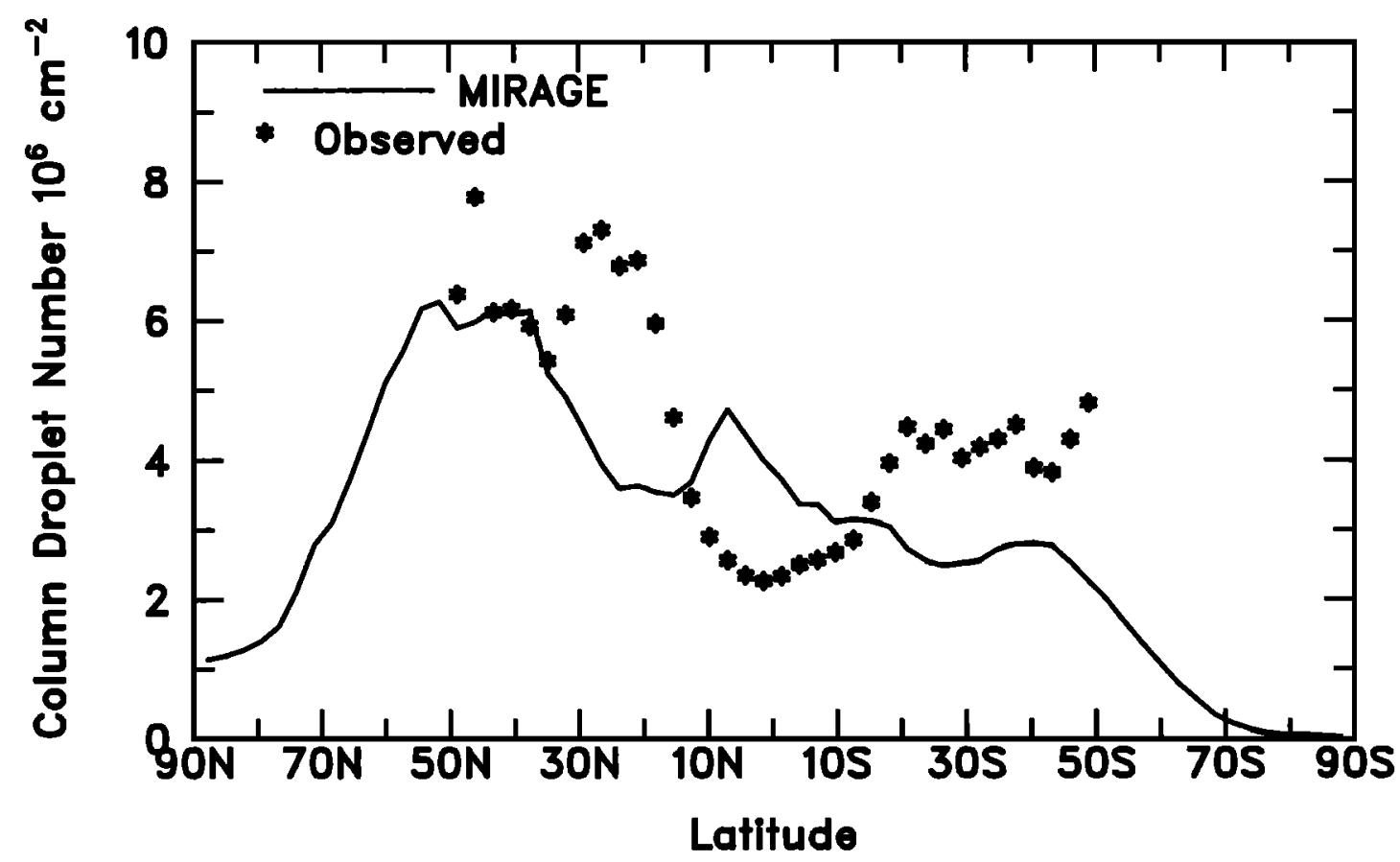

Figure 8. As in Figure 7 but for zonal means.

[Nakajima et al., 1991]. MIRAGE correctly simulates smaller droplets over the continents than over the oceans but underestimates the droplet radius by $1-3 \mu \mathrm{m}$ over most of the oceans. This bias may be due to the difference between the droplet size measured at cloud top and the cloud-waterweighted mean droplet size diagnosed from the MIRAGE simulation. In both the MIRAGE simulation and the observations the droplet radius tends to be somewhat smaller in the more polluted Northern Hemisphere. However, the observations are limited to latitudes $50^{\circ} \mathrm{S}$ to $50^{\circ} \mathrm{N}$, so conclusions cannot be drawn for the polar latitudes.

An alternate analysis of cloud droplet radius is based on the analysis of Polarization and Directionality of the Earth's Reflectances (POLDER) polarimeter measurements [Bréon and Goloub, 1998]. In addition to its multispectral and multidirectional capabilities, POLDER provided measurements of the linear polarization of the reflected light. The analysis of POLDER measurements revealed unexpected polarization features over some cloud fields [Bréon and Goloub, 1998]: minima and maxima of the polarization as a function of the scattering angle within the range $145^{\circ}-170^{\circ}$. Such features result from a narrow droplet size distribution, for liquid clouds, which yield an oscillating polarized phase function in this scattering angle range. Bréon and Goloub developed an inversion method based on these findings. The inversion compares the measured polarization to a number of cloud droplet distributions with different effective radii. The method has several limitations: it may retrieve a valid radius only if (1) the cloud field is homogeneous over a distance of roughly $150 \mathrm{~km}$, (2) some specific viewing geometry conditions are met, and (3) the droplet size distribution is relatively narrow. On the other hand, if such conditions are met, the method is highly accurate and reliable. Because the polarization is most sensitive to single scattering, the retrieved radii are representative of the cloud top, i.e., an optical depth of roughly 1 .
Given the special conditions required for the POLDER droplet radius analysis, full global coverage is only possible for averages over multiple months. Figure 11 compares the zonal land and ocean mean cloud droplet radius simulated by MIRAGE for June 1994 to May 1995 with that estimated from POLDER measurements for November 1996 to June 1997. Again, the land-ocean contrast in droplet radius is clearly evident in both the simulation and the POLDER analysis. The smaller droplet sizes in Antarctica and in the eastern Pacific off the coast of Baja California are correctly simulated, but MIRAGE overestimates droplet size in many regions, particularly in the midlatitude storm track of the Southern Hemisphere. MIRAGE overestimates droplet size at almost all latitudes, with the largest errors near $70^{\circ} \mathrm{S}$ and over the subtropical continents. The global mean simulated effective radius is 10.83 for land and 11.84 for ocean; the global mean observed effective radius is $\mathbf{8 . 6 1}$ for land and $\mathbf{1 0 . 9 6}$ for ocean. Given the tendency for droplet radius to be largest near cloud top, the droplet radius bias in the MIRAGE simulation cannot be explained by the fact that the POLDER analysis is more characteristic of the droplet radius at cloud top, while the MIRAGE estimate is weighted by the cloud water throughout the atmospheric column. However, the bias is opposite to the bias evident in the comparison with the Han et al. [1994] analysis, indicating some uncertainty in the observations. Yet the simulations and both analyses are consistent in their estimate of larger droplets over the oceans than over land.

\subsection{Cloud Optical Depth}

The cloud optical depth combines the influence of liquid water path and effective radius. In MIRAGE the cloud optical depth is related to the effective radii of droplets and ice crystals and to the column loading of cloud liquid water and cloud ice [Ghan et al., 1997a]. Figure 12 compares the 

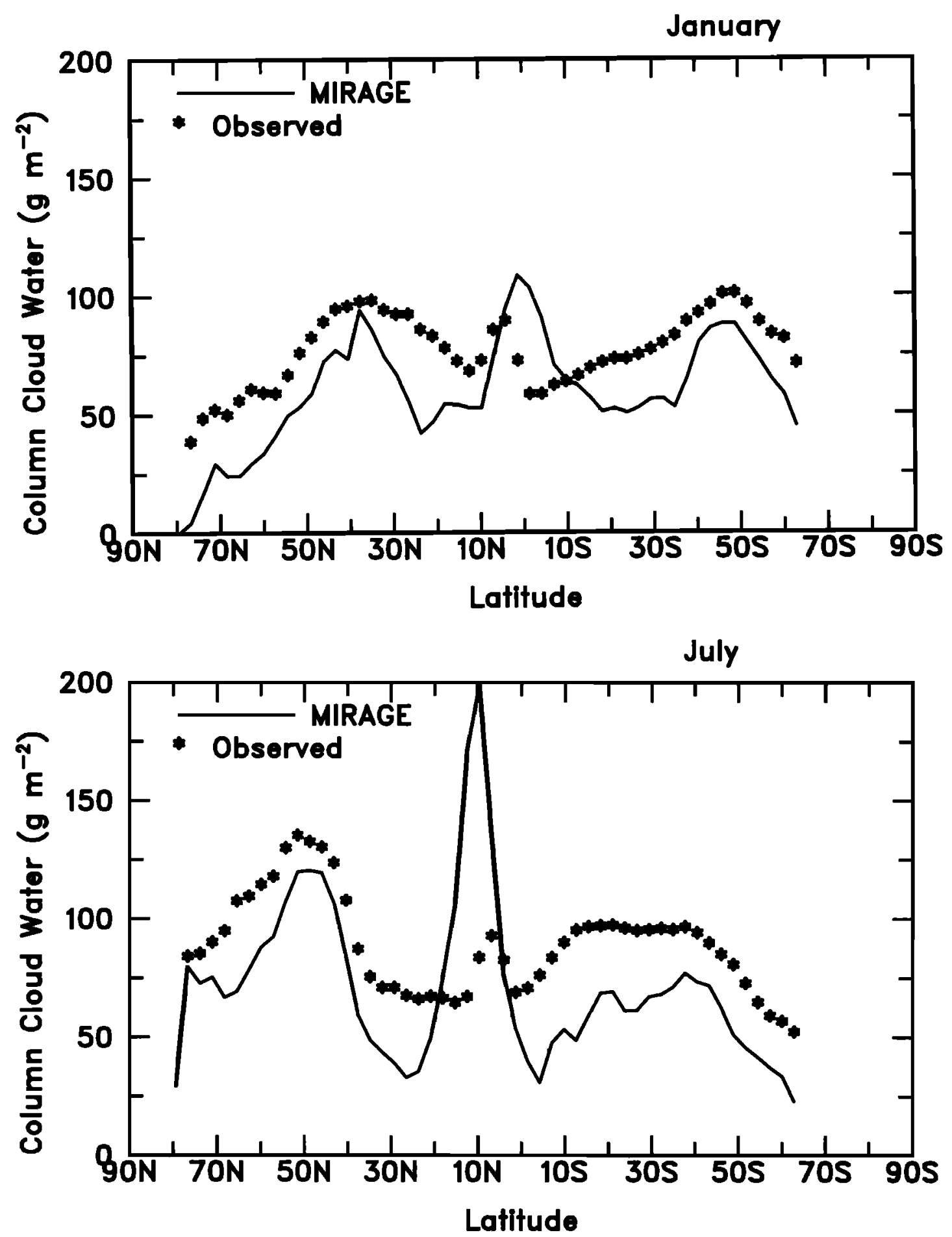

Figure 9. Ocean zonal mean column cloud water $\left(\mathrm{g} \mathrm{m}^{-2}\right)$ simulated by MIRAGE and estimated from Special Sensor Microwave/Imager measurements for January (top) and July (bottom).

zonal mean cloud optical depth simulated by MIRAGE and estimated from satellite measurements by ISCCP [Rossow and Lacis, 1990] for January and July. MIRAGE overestimates the monthly mean cloud optical depth in most regions except in West Africa in January and North America and central Asia in July. The simulated zonal mean cloud optical depth is about double the observed optical depth at almost all latitudes. The ITCZ is clearly too strong in the MIRAGE simulation, particularly in July. This bias is con- sistent with the excessive cloud liquid water path in the ITCZ, but the excessive cloud optical depth in the subtropics is inconsistent with the underpredicted cloud liquid water path there.

Further information about the relationship between cloud optical depth and cloud droplet effective radius is provided by Han et al. [1998a], who used satellite measurements to determine the temporal correlation between cloud albedo and droplet effective radius. They found that over the oceans the 

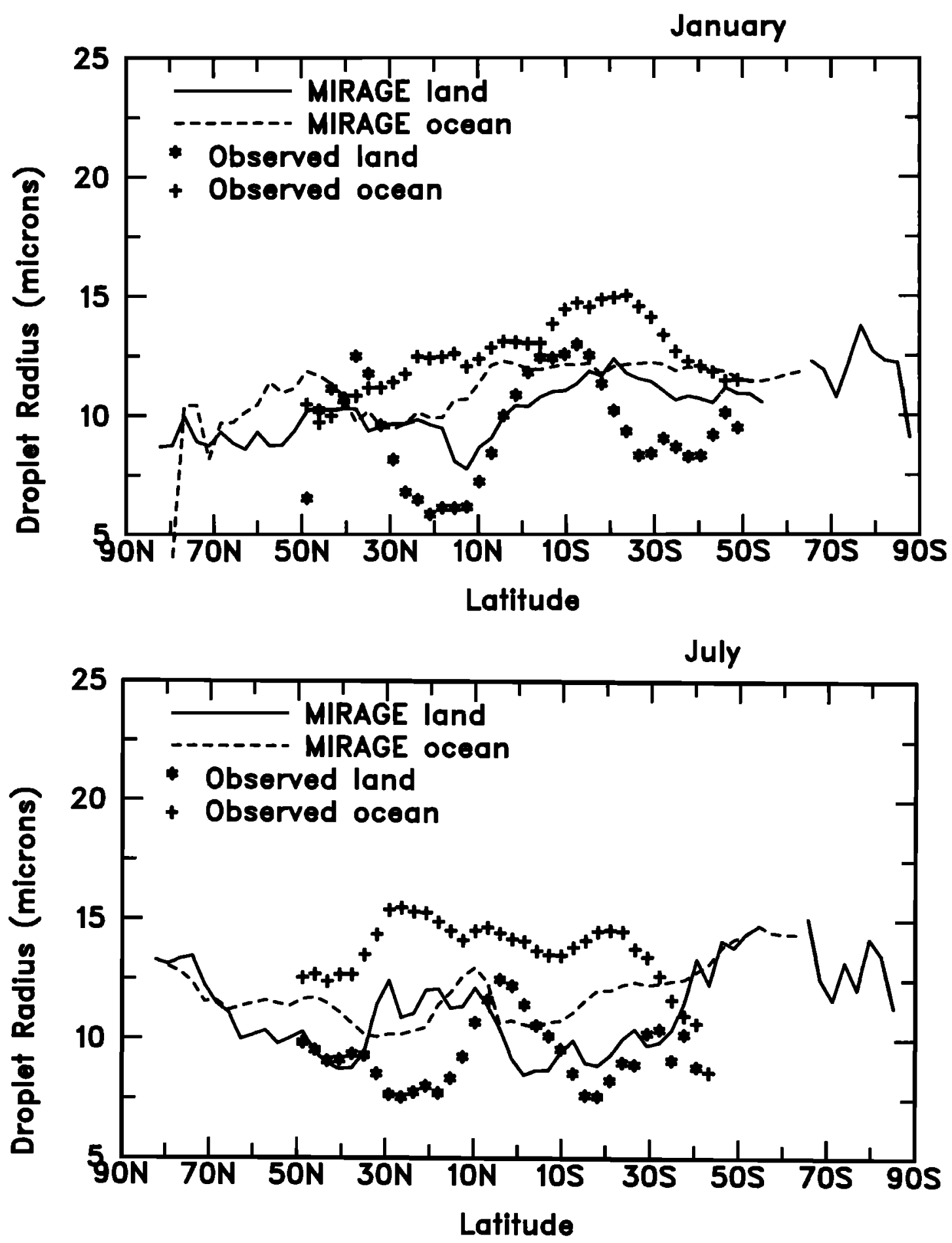

Figure 10. Land and ocean zonal mean cloud droplet effective radius simulated by MIRAGE and estimated by Han et al. [1994] from International Satellite Cloud Climatology Project (ISCCP) data for January (top) and July (bottom).

correlation is positive for cloud optical depths less than 15 but negative for cloud optical depths greater than 15. Over land they found a negative correlation for all cloud optical depths. The zonal land and ocean means of the temporal correlation between cloud optical depth (a surrogate for cloud albedo) and droplet effective radius as simulated by MIRAGE are illustrated in Figure 13. Over the remote oceans, MIRAGE successfully simulates a negative correlation for optical depths greater than 15 and a positive correlation for optical depths less than 15. However, MIRAGE fails to simulate a negative correlation over land for thin or thick clouds. Although the correlation simulated over land is less than that over ocean for optically thin clouds (which is consistent with observations), it is much greater for optically thick clouds (which is inconsistent with observations). Lohmann et al. $[1999,2000]$ find similar results in simulations by a version 


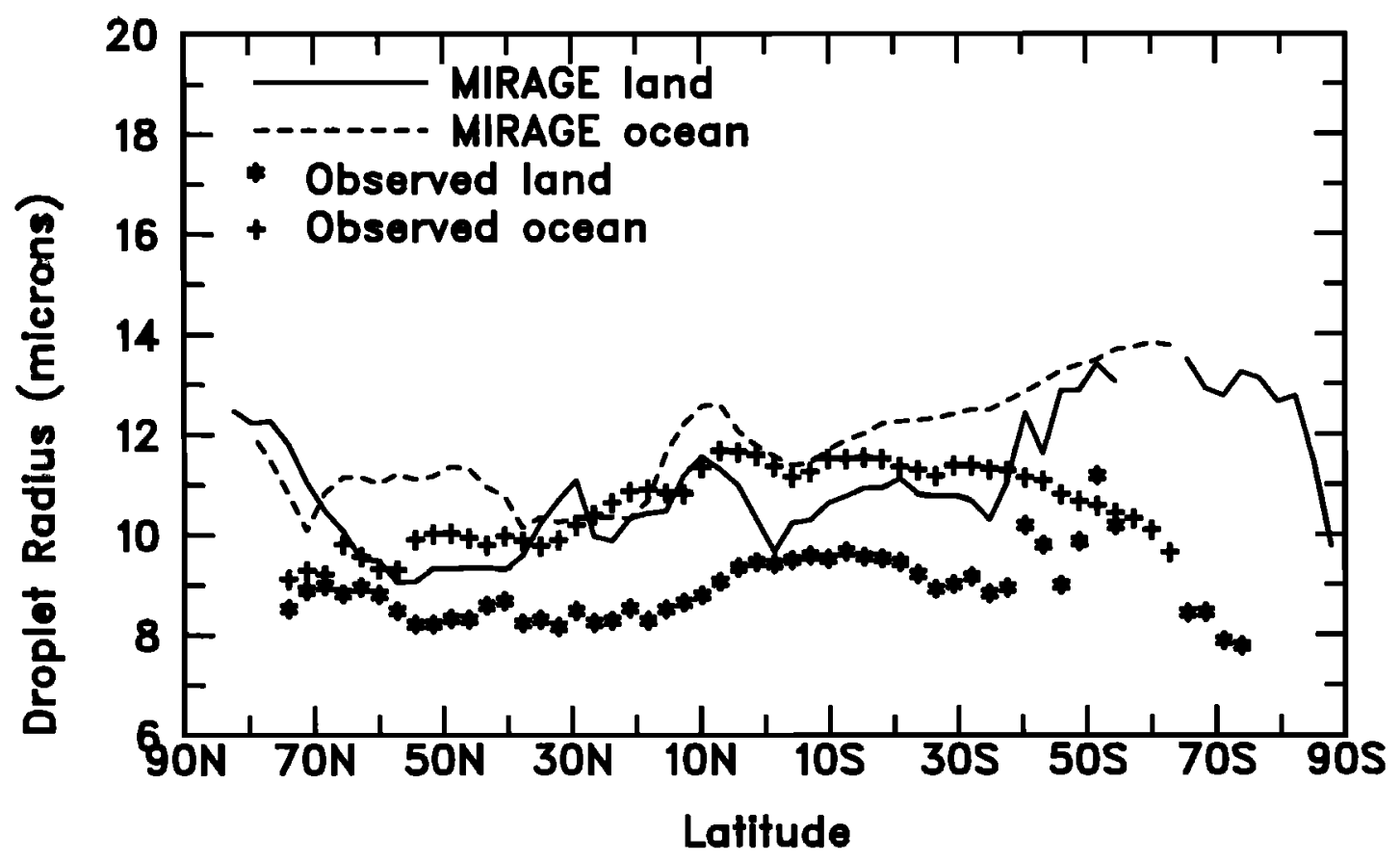

Figure 11. Land and ocean zonal mean cloud droplet effective radius (microns) simulated MIRAGE for June 1994 to May 1995 and estimated from POLDER measurements for November 1996 to June 1997.

of the ECHAM model that predicts droplet number in a manner very similar to MIRAGE. As MIRAGE, the ECHAM model successfully simulates a negative correlation over remote oceans for optical depths greater than 15 and a positive correlation for optical depths less than 15 , and fails to simulate a negative correlation over land for thin clouds. However, unlike MIRAGE, the ECHAM model successfully simulates a negative correlation over land for cloud optical depths exceeding 15. The agreement between MIRAGE and ECHAM is better than the agreement between MIRAGE and the observations, which is to be expected because the parameterizations used in MIRAGE and ECHAM are very similar.

\subsection{Cloud Radiative Forcing}

Although the time mean cloud optical depth simulated by MIRAGE appears to be far too high, the bias is not evident in the time mean cloud radiative forcing. Figure 14 compares the zonal mean shortwave cloud forcing simulated by MIRAGE and observed by ScaRaB [Kandel et al., 1998] for January 1995 and July 1994, respectively. The simulated zonal mean shortwave cloud forcing is within $25 \mathrm{~W} \mathrm{~m}^{-2}$ of the ScaRaB estimate at most latitudes, with excessively strong forcing in the ITCZ (particularly in July) and in the subtropics of the Southern Hemisphere, and weak cloud forcing at latitudes $55^{\circ} \mathrm{S}-75^{\circ} \mathrm{S}$ in January. The cloud forcing simulated in the ITCZ is not nearly so strong if the simulated winds are not nudged toward the analyzed winds, indicating that the excessively strong bias in the ITCZ is probably due to differences in the deep convection parameterizations in MIRAGE and the ECMWF analysis model. The apparent inconsistency between the excessive cloud optical depth and the much more realistic cloud radiative forcing has been explained by Ghan et al. [1997a] in terms of the variability of cloud optical depth.
For completeness, Figure 15 compares the simulated and observed zonal mean longwave cloud forcing for January and July. MIRAGE simulates the gross features of the longwave cloud forcing quite well, including the maxima in the midlatitudes of each hemisphere and in the ITCZ and the minima in the subtropics and the polar regions. The zonal mean longwave cloud forcing is underestimated by about $10 \mathrm{~W} \mathrm{~m}^{-2}$ in the ITCZ and overestimated in latitudes $50^{\circ}-90^{\circ} \mathrm{N}$ and $70^{\circ}-$ $90^{\circ} \mathrm{S}$.

The global means of the simulated and observed cloud radiative forcing are listed in Table 2 . The agreement is to within $2 \mathrm{~W} \mathrm{~m}^{-2}$ except for the shortwave cloud forcing in July, when MIRAGE overestimates the shortwave cloud forcing by $10 \mathrm{~W} \mathrm{~m}^{-2}$. The overestimate in July is due to the excessively strong ITCZ when MIRAGE is nudged by the ECMWF analyses; the shortwave cloud forcing in MIRAGE simulations without nudging is much closer to observations.

\section{Summary}

Although measurements are not available to evaluate directly the estimate of aerosol indirect radiative forcing by integrated models such as MIRAGE, measurements of many of the links between aerosols and radiative forcing are available. These links include the $\mathrm{CCN}$ concentration, the ratio of droplet number to aerosol number, the droplet number concentration, the column droplet number, the column cloud water, the droplet effective radius, the cloud optical depth, the correlation between cloud albedo and droplet effective radius, and the cloud radiative forcing. In this paper we have compared measurements of each of these fields with the simulation by MIRAGE.

The agreement between simulated and observed $\mathrm{CCN}$ concentration is quite good at supersaturations between 0.1 and 

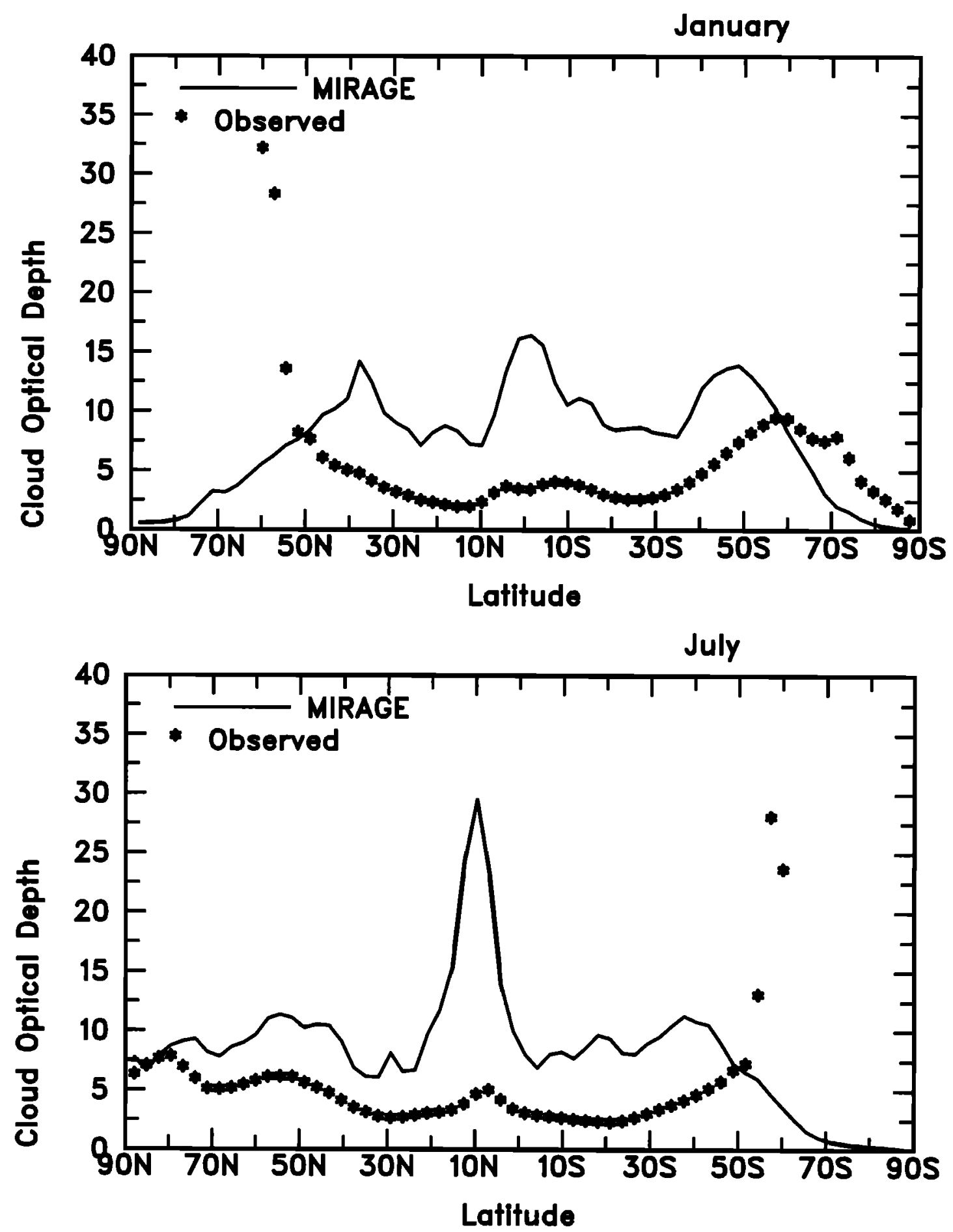

Figure 12. Zonal mean cloud optical depth simulated by MIRAGE and estimated from satellite measurements by ISCCP for January (top) and July (bottom).

$1 \%$ but not at $0.02 \%$. The disagreement at $0.02 \%$ could be due to the absence of certain types of coarse aerosols in MIRAGE or due to biases in the measurement of the CCN concentration at $0.02 \%$.

MIRAGE correctly simulates the decrease in the ratio of droplet number to aerosol number with increasing aerosol number but generally underestimates the ratio at all aerosol number concentrations. MIRAGE correctly simulates the higher droplet number concentrations in continental air compared with marine air. MIRAGE underestimates droplet number concentrations at most but not all locations where measurements are available. The MIRAGE simulation of column droplet number concentration is in general agreement with satellite analyses, except over desert regions where the satellite analysis is unable to distinguish between cloud droplets and dust particles. MIRAGE simulates the high column 

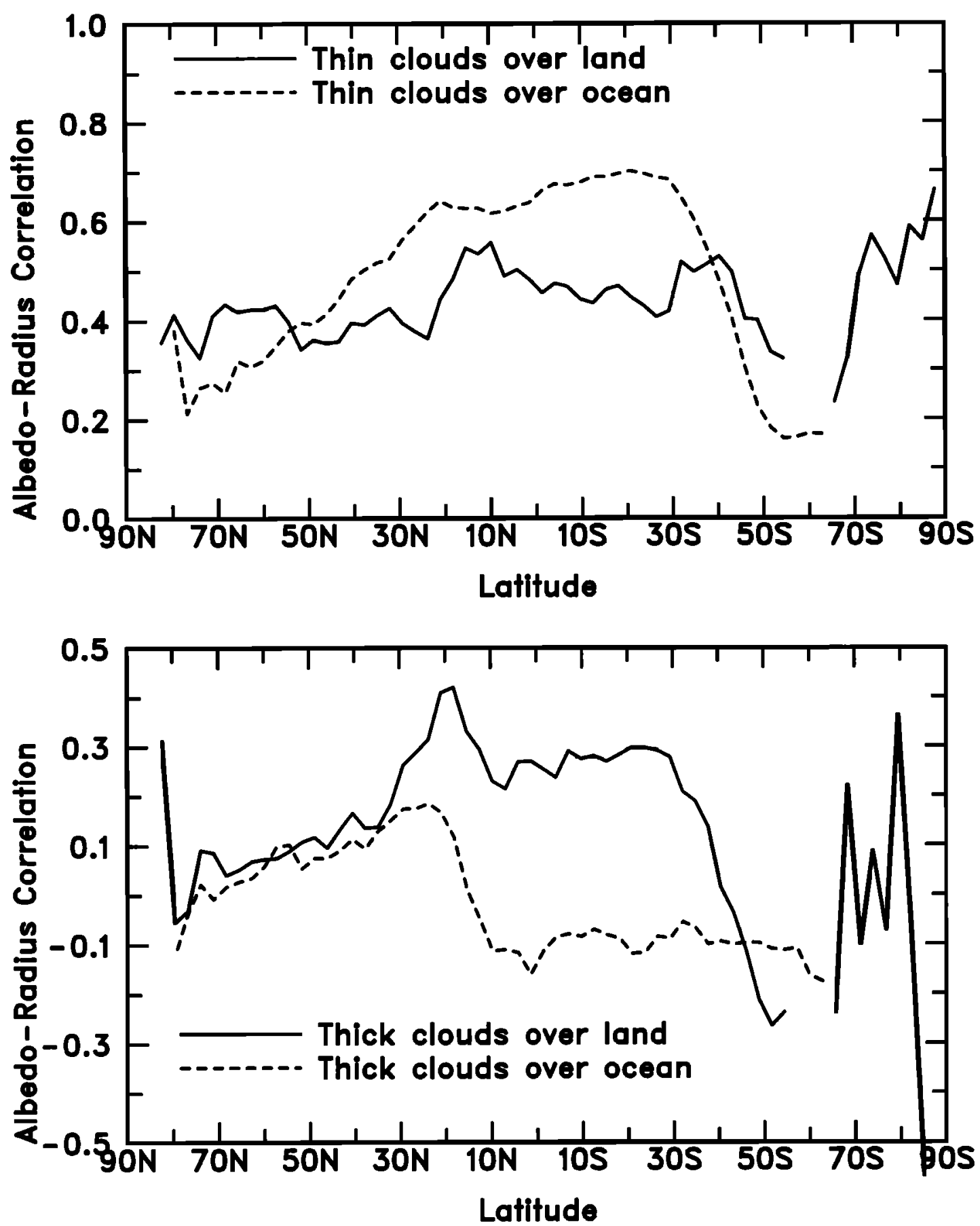

Figure 13. Zonal land and ocean mean annual temporal correlation between cloud optical depth and droplet effective radius simulated by MIRAGE for cloud optical depths less than 15 (top) and greater than 15 (bottom), computed with hourly cloud optical depth and column-averaged droplet effective radius values.

cloud water in the midlatitude storm tracks quite well but underestimates the column cloud water in the subtropical marine stratocumulus. In addition, when nudging of the winds toward the ECMWF analysis is applied, MIRAGE overestimates the column cloud water in the ITCZ. These biases are characteristic of many climate models.

MIRAGE correctly simulates the smaller droplet effective radius over the continents compared with over the oceans and in the Northern Hemisphere compared with in the Southern
Hemisphere. The biases appear to be within the uncertainty in the observations.

MIRAGE systematically overestimates the cloud optical depth, except in polar latitudes. The bias is particularly evident in the ITCZ, where the optical depth simulated by MIRAGE is about triple the observed value, and is consistent with the excessive column cloud water simulated there. However, the excessive cloud optical depth in the subtropics is apparently inconsistent with the low column cloud water 

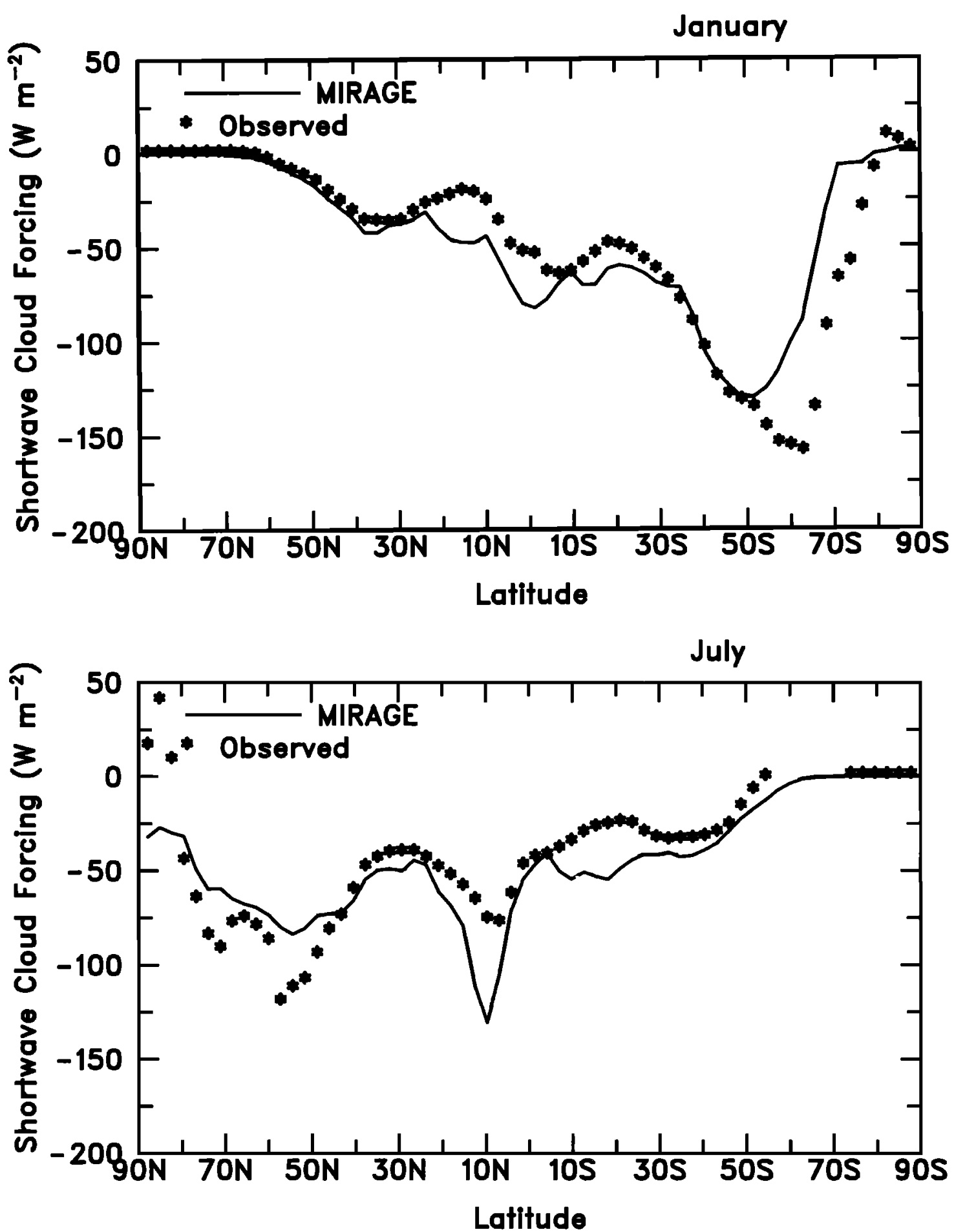

Figure 14. Zonal mean shortwave cloud forcing simulated by MIRAGE and observed by ScaRaB for January 1995 (top) and July 1994 (bottom).

simulated there. The biases in the droplet effective radius do not reconcile this inconsistency because the two satellite retrievals differ significantly.

MIRAGE correctly simulates a negative correlation between cloud optical depth (cloud albedo) and droplet effective radius over remote oceans for cloud optical depths greater than 15 and a positive correlation for cloud optical depths less than 15. However, MIRAGE fails to simulate the observed negative correlation over land for either thin or thick clouds.

The cloud radiative forcing simulated by MIRAGE agrees quite well with observations. The simulated shortwave cloud forcing is too strong in the ITCZ and is too weak in the midlatitude storm track of the Southern Hemisphere and in stratocumulus regions.

To summarize, MIRAGE tends to simulate too few cloud 

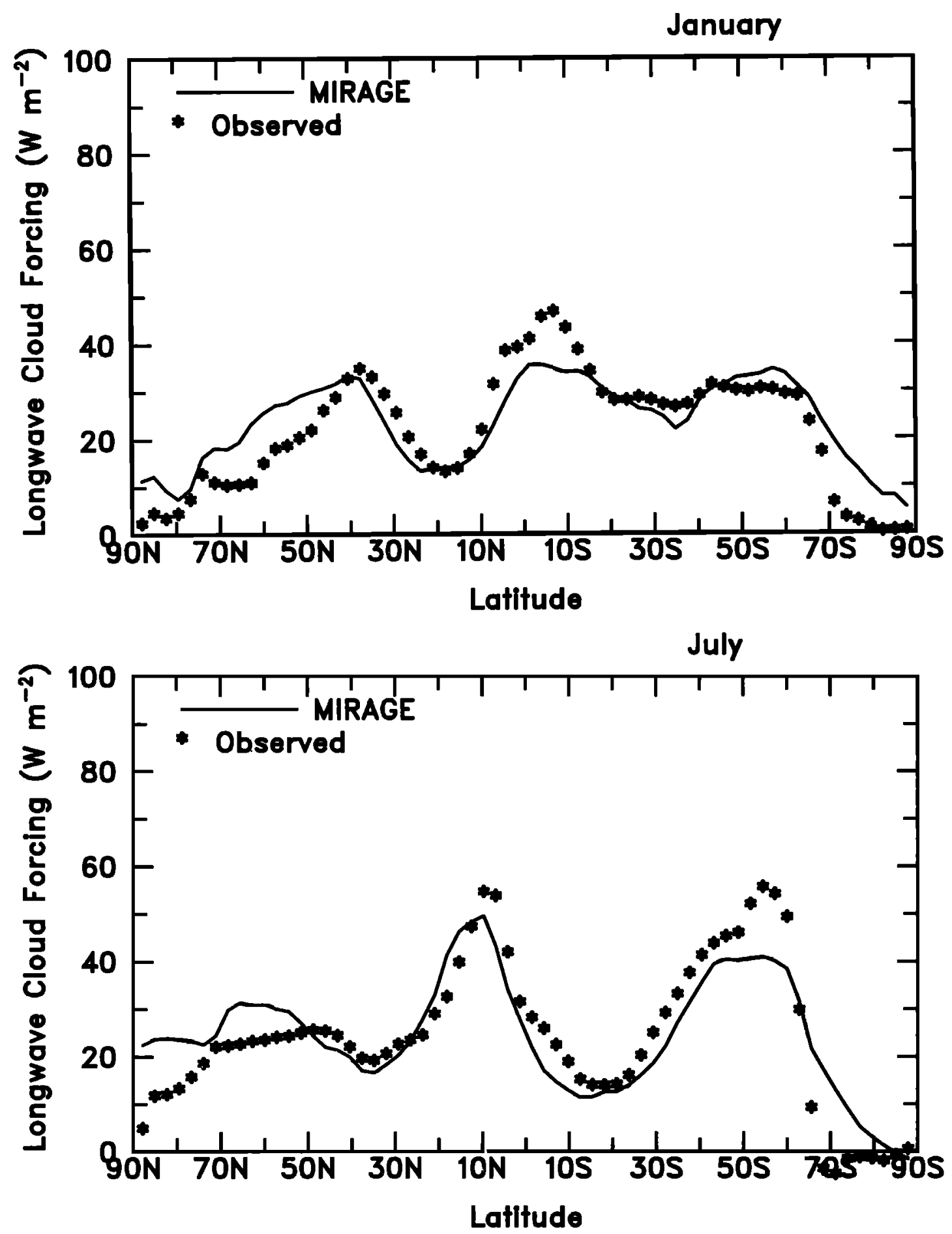

Figure 15. Zonal mean longwave cloud forcing simulated by MIRAGE and observed by ScaRaB for January 1995 (top) and July 1994 (bottom).

droplets and excessive cloud optical depths, but the droplet effective radius and cloud radiative forcing are simulated quite well. Sensitivity experiments with prescribed droplet number indicate that the cloud optical depth bias is not explained by the bias in droplet number concentration. The ITCZ is too strong in simulations nudged toward the ECMWF-analyzed winds but not in simulations without nudging.

How might the biases in the MIRAGE simulation of indirect forcing and associated fields be corrected?
1. Biases in the aerosol concentrations [E2000] must be corrected. MIRAGE underestimates organic carbon, dust, and sea-salt aerosol and ovérestimates sulfate aerosol above the planetary boundary layer. Some of these biases are due to deficiencies in the treatment of wet removal, but others are due to problems with the emissions. Given the importance of competition between particles when droplets are nucleated [Ghan et al., 1998], reduction of these biases is essential if uncertainty in estimates of indirect forcing is to be reduced. Emissions of natural aerosol and their precursors are par- 
Table 2. Monthly Mean Cloud Radiative Forcing $\left(\mathrm{W} \mathrm{m}^{-2}\right)$ As Simulated by MIRAGE and As Estimated From ScaRaB Measurements

\begin{tabular}{lccccc}
\hline & \multicolumn{2}{c}{ January 1995} & & \multicolumn{2}{c}{ July 1994} \\
\cline { 2 - 3 } \cline { 5 - 6 } \cline { 5 - 6 } & Observed & MIRAGE & & Observed & MIRAGE \\
\hline $\begin{array}{l}\text { Shortwave cloud } \\
\text { forcing }\end{array}$ & -53.3 & -55.4 & & -49.1 & -58.6 \\
$\begin{array}{c}\text { Longwave cloud } \\
\text { forcing }\end{array}$ & 25.8 & 25.8 & & 27.1 & 25.8 \\
\hline
\end{tabular}

ticularly important because they control the susceptibility of cloud albedo to the addition of anthropogenic aerosol.

2. The treatment of droplet nucleation must be improved. Although the parameterization of the process [Abdul-Razzak and Ghan, 2000] agrees with detailed simulations very well, the simulated droplet number concentrations normalized by aerosol number concentrations are typically lower than observed. Droplet loss due to collision/coalescence and mixing/evaporation could be modified, but improvements in droplet number are more likely with the addition of a badly needed treatment of subgrid cloud in MIRAGE. The influence of soluble gases [Kulmala et al., 1998] and surfactants [Schulman et al., 1996; Li et al., 1998; Facchini et al., 1999] on droplet nucleation have been shown to be important at times and hence also need to be treated.

3. The sensitivity of stratocumulus cloud to vertical resolution (a problem common to all climate models) needs to be reduced. This is a problem of active research with excellent prospects for significant advances.

4. The cloud water in the tropics is much too sporadic, with infrequent optically thick clouds and frequent clear conditions. This bias is related to the treatment of cumulus convection, which in MIRAGE is relatively crude. The next generation of MIRAGE will use a more advanced cumulus parameterization [Zhang and McFarlane, 1995], which diagnoses convective cloud water and produces deeper penetration of the convective towers. This will also provide the ability to treat indirect forcing associated convective clouds.

5. A subgrid treatment of stratiform clouds is needed to provide a more continuous transition between clear and overcast conditions.

Acknowledgments. This study was primarily supported by the NASA Earth Science Enterprise under contract NAS5-98072 and grants NAG5-8797 and NAG5-9531, and by the NOAA/NASA Climate Change and Data Detection Program under grant NA67RJ0146. Support was also provided by the U.S. Department of Energy Atmospheric Radiation Measurement Program, which is part of the DOE Biological and Environmental Research Program. The Pacific Northwest National Laboratory is operated for the DOE by Battelle Memorial Institute under contract DE-AC06-76RLO 1830. M. Viollier provided the ScaRaB Earth radiation budget data. Joyce Chou and Qingyuan Han provided their satellite estimates of droplet radius, droplet radius-cloud albedo correlation, and column droplet number.

\section{References}

Abdul-Razzak, H., and S. J. Ghan, A parameterization of aerosol activation, 2, Multiple aerosol types, J. Geophys. Res., 105, 6837$6844,2000$.

Abdul-Razzak, H., S. J. Ghan, and C. Rivera-Carpio, A parameterization of aerosol activation, 1, Single aerosol type, J. Geophys. Res., 103, 6123-6132, 1998.

Baker, M., and R. J. Charlson, Bistability of $\mathrm{CCN}$ concentrations and thermodynamics in the cloud-topped boundary layer, Nature, 34.5, 142-145, 1990.
Boers, R., and P. B. Krummel, Microphysical properties of boundary layer clouds over the Southern Ocean during ACE 1, J. Geophys. Res., 103, 16,651-16,663, 1998.

Boers, R., J. B. Jensen, P. B. Krummel, and H. Gerber, Microphysical and radiative structure of wintertime stratocumulus clouds over the Southern Ocean, Q.J.R. Meteorol. Soc., 122, 1307-1339, 1996.

Boers, R., J. B. Jensen, P. B. Krummel, Microphysical and shortwave radiative structure of stratocumulus clouds over the Southern Ocean: Summer results and seasonal differences, Q.J.R. Meteorol. Soc., 122, 151-168, 1998.

Boucher, O., and U. Lohmann, The sulfate-CCN-cloud albedo effect: A sensitivity study with two general circulation models, Tellus, Ser. B, 47, 281-300, 1995.

Bréon, F.-M., and P. Goloub, Cloud droplet effective radius from spaceborne polarization measurements, Geophys. Res. Lett., 25, 1879-1882, 1998.

Charlson, R. J., S. E. Schwartz, J. M. Hales, R. D. Cess, J. A Coakley Jr., J. E. Hansen, and D. J. Hoffman, Climate forcing by anthropogenic aerosols, Science, 2.55, 423-430, 1992.

Chuang, C. C., J. E. Penner, K. E. Taylor, A. S. Grossman, and J. J. Walton, An assessment of the radiative effects of anthropogenic sulfate, J. Geophys. Res., 102, 3761-3778, 1997.

Cotton, W. R., G. J. Tripoli, R. M. Rauber, and E. A. Mulvihill, Numerical simulation of the effects of varying ice crystal nucleation rates and aggregation processses on orographic snowfall, J. Clim. Appl. Meteorol., 2.5, 1658-1680, 1986.

Facchini, M. C., M. Mircea, S. Fuzzi, and R. J. Charlson, Cloud albedo enhancement by surface-active organic solutes in growing droplets, Nature, 401, 257-259, 1999.

Feichter, J., and U. Lohmann, Can a relaxation technique be used to validate clouds and sulfur species in a GCM?, Q.J.R. Meteorol. Soc., 125, 1277-1294, 1999.

Fouquart, Y., and H. Isaka, Sulfur emission, CCN, clouds and climate: A review, Ann. Geophys., 10, 462-471, 1992.

Ghan., S. J., and R. C. Easter, Computationally efficient approximations to stratiform cloud microphysics parameterization, Mon. Weather Rev., 120, 1572-1582, 1992.

Ghan, S. J., L. R. Leung, and Q. Hu, Application of cloud microphysics to NCAR CCM2, J. Geophys. Res., 102, 16,507$16,528,1997 \mathrm{a}$.

Ghan, S. J., L. R. Leung, R. C. Easter, and H. Abdul-Razzak, Prediction of droplet number in a general circulation model, J. Geophys. Res., 102, 21,777-21,794, 1997b.

Ghan, S. J., G. Guzman, and H. Abdul-Razzak, Competition between sea salt and sulfate particles as cloud condensation nuclei, J. Atmos. Sci., 55, 3340-3347, 1998.

Ghan, S., N. Laulainen, R. Easter, R. Wagener, S. Nemesure, E. Chapman, Y. Zhang, and R. Leung, Evaluation of aerosol direct radiative forcing in MIRAGE, J. Geophys. Res., this issue (a).

Ghan, S. J., R. C. Easter, E. Chapman, H. Abdul-Razzak, Y. Zhang, R. Leung, N. Laulainen, R. Saylor, and R. Zaveri, A physically based estimate of radiative forcing by anthropogenic sulfate aerosol, J. Geophys. Res., this issue (b).

Gillani, N. V., S. E. Schwartz, W. R. Leaitch, J. W. Strapp, and G. A. Isaac, Field observations in continental clouds: Partitioning of cloud particles between droplets and unactivated interstitial aerosols, J. Geophys. Res., 100, 18,687-18,706, 1995.

Greenwald, T. J., G. L. Stephens, S. A. Christopher, and T. H. Vonder Haar, Observations of the global characteristics and regional radiative effects of marine cloud liquid water, J. Clim., 8 , 2928-2946, 1995.

Gultepe, I., G. A. Isaac, W. R. Leaitch, and C. M. Banic, 
Parameterizations of marine stratus microphysics based on in situ observations: Implications for GCMs, J. Clim., 9, 345-357, 1996.

Han, Q., W. B. Rossow, and A. A. Lacis, Near-global survey of effective droplet radii in liquid water clouds using ISCCP data, J. Clim., 7, 465-497, 1994.

Han, Q., W. B. Rossow, J. Chou, and R. Welch, Global survey of the relationships of cloud albedo and liquid water path with droplet size using ISCCP data, J. Clim., 11, 1516-1528, 1998a

Han, Q., W. B. Rossow, J. Chou, and R. Welch, Global variation in column droplet concentration in low-level clouds, Geophys. Res. Lett., 25, 1419-1422, 1998 b.

Hudson, J. G., An instantaneous CCN spectrometer, J. Atmos. Ocean Technol., 6, 1055-1065, 1989.

Hudson, J. G., Cloud condensation nuclei, J. Appl. Meteorol., 32, 596-607, 1993.

Hudson, J. G., and H. Li, Microphysical contrasts in Atlantic stratus, J. Atmos. Sci., 52, 3031-3040, 1995.

Hudson, J. G., and Y. Xie, Vertical distributions of cloud condensation nuclei spectra over the summertime Northeast Pacific and Atlantic Oceans, J. Geophys. Res., 104, 30,219. $30,230,1999$.

Hudson, J. G., and S. S. Yum, Maritime/continental drizzle contrasts in small cumuli, J. Atmos. Sci., in press, 1999.

Hudson, J. G., Y. Xie, and S. S. Yum, Vertical distributions of cloud condensation nuclei spectra over the summertime Southern Ocean, J. Geophys. Res., 103, 16,609-16,624, 1999.

Intergovernmental Panel on Climate Change (IPCC), Climate Change 1994, 339 pp., Cambridge Univ. Press, New York, 1995.

Jones, A., and A. Slingo, Predicting cloud-droplet effective radius and indirect sulphate aerosol forcing using a general circulation model, Q.J.R. Meteorol. Soc., 122, 1573-1595, 1996.

Jones, A., D. L. Roberts, and A. Slingo, A climate model study of indirect radiative forcing by anthropogenic aerosols, Nature, 370 , 450-453, 1994.

Kandel, R., M. Viollier, P. Raberanto, J. P. Duvel, L. A. Pakhomov, V. A. Golovko, A. P. Trishchenko, J. Mueller, E. Raschke, R. Stuhlmann, and the International ScaRaB Scientıfic Working Group, The ScaRaB earth radiation budget data set, Bull. Am. Meteorol. Soc., 79, 765-783, 1998.

Kiehl, J. T., T. L. Schneider, P. J. Rasch, M. C. Barth, and J. Wong Radiative forcing due to sulfate aerosols from simulations with the NCAR community climate model, J. Geophys. Res., 10.5, 1441-1457, 2000.

King, M. D., S.-C. Tsay, and S. Platnick, In situ observations of the indirect effects of aerosols on clouds, in Aerosol Forcing of Climate, edited by R. J. Charlson and J. Heintzenberg, 416 pp., John Wiley, New York, 1995.

Kulmala, M., A. Toivonen, T. Mattila, and P. Korhonen, Variations of cloud droplet number concentrations and the optical properties of clouds due to changing hygroscopicity: A model study, J. Geophys. Res., 103, 16,183-16,195, 1998.

Leaitch, W.R., G.A. Isaac, J.W. Strapp, C.M. Banic, and H.A. Wiebe, The relationship between cloud droplet number concentrations and anthropogenic pollution: Observations and climatic implications. J. Geophys. Res., 97, 2463-2474, 1992.

Leaitch, W. R., C. M. Banic, G. A. Isaac, M. D. Conture, P.S.K. Liu I. Gultepe, S.-M.. Li, L. Kleinman, P. H. Daum, and J. I. MacPherson, Physical and chemical observations in marine stratus during the 1993 North Atlantic Regional Experiment: Factors controlling cloud droplet number concentrations, J. Geophys. Res., 101, 29,123-29,135, 1996.

Li, Z., A. L. Williams, and M. J. Rood, Influence of soluble surfactant properties on the activation of aerosol particles containing inorganic solute, J. Atmos. Sci., 55, 1859-1866, 1998.

Lighthart, B., and B. T. Shaffer, Bacterial flux from chaparral into the atmosphere in midsummer at a high desert location, Atmos. Environ., 28, 1267-1274, 1994.

Lin, H., and R. Leaitch, Development of an in-cloud aerosol. activation parameterization for climate medeling, paper presented at World Meteorology Organization Workshop, Nat. Univ. Mex., Mexico City, June 23-27, 1997.

Lohmann, U., and J. Feichter, Impact of sulfate aerosols on albedo and lifetime of clouds: A sensitivity study with the ECHAM4 GCM, J. Geophys. Res., 102, 13,685-13,700, 1997.

Lohmann, U., J. Feichter, C. C. Chuang, and J. E. Penner, Predicting the number of cloud droplets in the ECHAM GCM, J. Gerophys: Res, 104, 9169-9198, 1999.
Lohmann, U., G. Tselioudis, and C. Tyler, Why is the cloud albedo particle size relationship different in optically thick and optically thin clouds?, Geophys. Res. Lett., 27, 1099-1 102, 2000.

Markowski, G. R., Improving Twomey's algorithm for inversion of aerosol measurement data, Aerosol Sci. Technol., 7, 127-141, 1987.

Matthias-Maser, S., and R. Jaenicke, Examination of atmospheric bioaerosol particles with radii $>0.2 \mu \mathrm{m}, J$. Aerosol. Sci., 25, 1605-1613, 1994.

Nakajima, T., M. D. King, and J. D. Spinhirne, Determination of the optical thickness and effective particle radius of clouds from reflected solar radiation measurements, II, Marine stratocumulus observations, J. Atmos. Sci., 48, 728-750, 1991.

National Research Council (NRC) Panel on Aerosol Radiative Forcing and Climate Change, in Aerosol Radiative Forcing and Climate Change, National Acad. Press, Washington, D. C., 1996.

Nichols, S., The dynamics of stratocumulus: aircraft observations and comparisons with a mixed layer model, Q.J.R. Meteorol. Soc., $110,783-820,1984$.

Penner, J. E., R. J. Charlson, J. M. Hales, N. S. Laulainen, R. Leifer, T. Novakov, J. Ogren, L. F. Radke, S. E. Schwartz, and L. Travis, Quantifying and minimizing uncertainty of climate forcing by anthropogenic aerosols, Bull. Am. Meteorol. Soc., 75, 375-400, 1994.

Rossow, W. B., and A. A. Lacis, Global, seasonal cloud variations from satellite radiance measurements, II, Cloud properties and radiative effects, J. Clim., 3, 1204-1253, 1990.

Rotstayn, L., Indirect forcing by anthropogenic aerosols: A global climate model calculation of the effective-radius and cloudlifetime effects, J. Geophys. Res, 104, 9369-9380, 1999.

Schulman, M. L., M. C. Jacobson, R .J. Charlson, R. E. Synovec, and T. E. Young, Dissolution behavior and surface tension effects of organic compounds in nucleating cloud droplets, Geophys. Res. Lett., 2.3, 277-280, 1996.

Squires, $P$.. The microstructure and colloidal stability of warm clouds, Tellus, 10, 256-271, 1958.

Tripoli, G. J., and W. R. Cotton, A numerical investigation of several factors contributing to the observed variable intensity of deep convection over south Florida, J. Appl. Meteorol., 19, 1037-1063, 1980.

Twomey, S., Comparison of constrained linear inversion and an iterative nonlinear algorithm applied to the indirect estimation of particle size distributions, J. Comput. Phys., 18, 188-200, 1975.

Twomey, S., Atmospheric Aerosols, Elsevier, New York, 1977.

Wendisch, M., A. Keil, and A. V. Korolev, FSSP characterization with monodisperse water droplets, J. Atmos. Oceanic Technol., $13,1152-1165,1996$.

Wood, R., et al., Boundary layer and aerosol evolution during the third Lagrangian experiment of ACE 2, Tellus, Ser. B, 52, 401$422,2000$.

Yamada, T., and G. L. Mellor, A numerical simulation of BOMEX data using a turbulence closure model coupled with ensemble cloud relations, Q.J.R. Meteorol. Soc., 105, 915-944, 1979.

Yum, S. S., and J. G. Hudson, Vertical distributions of cloud condensation nuclei spectra over the springtime Arctic Ocean, J. Geophys. Res., in press, 2000.

Yum, S. S., J. G. Hudson, and Y. Xie. Comparisons of cloud microphysics with cloud condensation nuclei spectra over the summertime Southern Ocean, J. Geophys. Res., 103, 16,625$16,636,1998$

Zhang, G. J., and N. A. McFarlane, Sensitivity of climate simulations to the parameterization of cumulus convection in the Canadian Climate Center general circulation model, Atmos.-Ocean, 33, 407 446, 1995.

Ziegler, C. L., Retrieval of microphysical variables in observed convective storms, 1, Model development and preliminary testing, J. Atmos. Sci., 42, 1487-1509, 1985.

F.-M. Bréon, CEA Laboratoire dés Sciences du Climat et de l'Environnement, Gif-sur-Yvette, France.

R. Easter and S. Ghan, Pacific Northwest National Laboratory, P.O. Box 999, MSIN K9-30, Richland, WA 99352. (richard.easter @pnl.gov; steve.ghan@pnl.gov)

J. Hudson, Desert Research Institute, Reno, NV 89512. (hudson @sage.dri.edu)

(Received October 28, 1999; revised June 6, 2000;

accepted August 9, 2000.) 